\title{
Bolide summer: The Paleocene/Eocene thermal maximum as a response to an extraterrestrial trigger
}

\author{
Benjamin S. Cramer ${ }^{a, *}$, Dennis V. Kent ${ }^{b, c}$ \\ anstitute of Geology and Paleontology, Tohoku University, Sendai, 982-0262, Japan \\ ${ }^{\mathrm{b}}$ Department of Geological Sciences, Rutgers University, Piscataway, NJ 08854, USA \\ ${ }^{\mathrm{c}}$ Lamont-Doherty Earth Observatory, Palisades, NY 10964, USA
}

Received 29 January 2004; received in revised form 7 September 2004; accepted 23 March 2005

\begin{abstract}
The standard paradigm that the Paleocene/Eocene thermal maximum (PETM) represents a threshold event intrinsic to Earth's climate and connected in some way with long-term warming has influenced interpretations of the geochemical, climate, and biological perturbations that occurred at this event. As recent high-resolution data have demonstrated that the onset of the event was geologically instantaneous, attempts to account for the event solely through endogenous mechanisms have become increasingly strained. The rapid onset of the event indicates that it was triggered by a catastrophic event which we suggest was most likely a bolide impact. We discuss features of the PETM that require explanation and argue that mechanisms that have previously been proposed either cannot explain all of these features or would require some sort of high-energy trigger. A bolide impact could provide such a trigger and, in the event of a comet impact, could contribute directly to the shape of the carbon isotope curve. We introduce a carbon cycle model that would explain the PETM by global warming following a bolide impact, leading to the oxidation of terrestrial organic carbon stores built up during the late Paleocene. Our intention is to encourage other researchers to seriously consider an impact trigger for the PETM, especially in the absence of plausible alternative mechanisms.
\end{abstract}

(C) 2005 Elsevier B.V. All rights reserved.

Keywords: Paleocene/Eocene thermal maximum; Carbon isotope excursion; Bolide impact; Methane hydrates; Carbon cycle; Bioevents

\footnotetext{
* Corresponding author. Present address: Department of Geological Sciences, University of Oregon, Eugene, OR 97403-1272, USA. Tel.: +1 5413464573; fax: +1 5413464692 .

E-mail addresses: bscramer@uoregon.edu (B.S. Cramer), dvk@rci.rutgers.edu (D.V. Kent).
}

\section{Introduction}

At the Paleocene/Eocene boundary, $\sim 55 \mathrm{Ma}$, a catastrophic event produced dramatic changes in Earth's biogeochemical systems. Global temperatures abruptly warmed by $4-5{ }^{\circ} \mathrm{C}$ at the same time when a perturbation to the biogeochemical carbon cycle led to a $>4 \%$ o decrease in atmospheric and surface ocean $\delta^{13} \mathrm{C}$ values 
and soon thereafter a $\sim 2.5 \% \circ \delta^{13} \mathrm{C}$ decrease in the deep ocean (e.g., Kennett and Stott, 1991). Major changes in community structure are recorded in marine microfossils (planktonic and benthic foraminifers, calcareous nannoplankton, dinoflagellates, ostracodes), including an extinction of $30-50 \%$ of species of bathyal-abyssal benthic foraminifers (e.g., Thomas, 1998). Terrestrial faunas were also affected, with the first appearance of most modern mammalian orders occurring at the P/E boundary (e.g., Maas et al., 1995).

In seeking the causes of this catastrophic event, most researchers have focused on the large decrease in $\delta^{13} \mathrm{C}$ values, which seemed too large and too rapid to be easily explained within the context of standard carbon cycle models. This led to the proposal that the large decrease reflected the input of substantial quantities of isotopically light methane from thermal dissociation of seafloor clathrate deposits (Dickens et al., 1995; Matsumoto, 1995). As discussed below, the documented rapidity of the onset of the event and lower estimates of the size of the methane hydrate reservoir indicate that this cannot be the major source for the carbon isotope excursion (CIE). Kurtz et al. (2003) showed that the late Paleocene was a time of increasing terrestrial organic carbon-rich deposition and suggested that the $\delta^{13} \mathrm{C}$ may have resulted from the burning of large peat deposits. With several coauthors, we have recently presented evidence that an extraterrestrial impact occurred at the onset of the PETM (Kent et al., 2003a), which would provide a trigger of sufficiently large energy to account for the rapidity of the onset of the event.

In this contribution, we explore the mechanisms by which an impact could trigger a "bolide summer:" the prolonged interval of warmth during the PETM. Our discussion focuses mainly on evidence for changes in the carbon cycle during the PETM, which we believe has been obscured in the literature by the emphasis on methane hydrate. As background, however, it is useful to summarize the published evidence for an impact at the $\mathrm{P} / \mathrm{E}$ boundary and for a major perturbation to biological systems, although only benthic foraminifers suffered a mass extinction during the PETM.

\subsection{Evidence for a $P / E$ impact}

In the first comprehensive study to consider the possibility that the PETM was caused by an impact
(Kent et al., 2003a), we proposed that (1) a published report of an iridium (Ir) anomaly coincident with the initial decrease in $\delta^{13} \mathrm{C}$ values and (2) discovery of abundant magnetic nanoparticles (a condensation product from the impact plume) in the interval of minimal $\delta{ }^{13} \mathrm{C}$ values at sites on the North American North Atlantic shelf could be taken as evidence for a bolide impact at the onset of the PETM. We suggested that the initial, rapid decrease in $\delta^{13} \mathrm{C}$ values could have resulted directly from a cometary impact, as cometary carbon is greatly enriched in ${ }^{12} \mathrm{C}$ (e.g., Arpigny et al., 2003; Messenger, 2000). The $\delta^{13} \mathrm{C}$ record cannot be taken as unique to an impact, since terrestrial ${ }^{12} \mathrm{C}$-enriched carbon could be the source, but the apparent extreme rapidity of the initial $\delta^{13} \mathrm{C}$ decrease is difficult to explain without a very highenergy trigger.

Increased levels of Ir have been reported associated with the P/E boundary in at least two locations. A small but reproducible Ir anomaly ( $\sim 140 \mathrm{ppt} \mathrm{Ir,} \mathrm{repro-}$ duced in samples collected in three different years) occurs precisely (centimeter scale) at the onset of the CIE at Zumaya, Spain (Schmitz et al., 1997). The small magnitude of this Ir anomaly lends itself to several possible explanations, although consideration of the stratigraphic, sedimentological, and geochemical context led Schmitz et al. (1997) to conclude that it was most likely due to either volcanism (for which no other evidence was presented) or an impact. A subsequent study resulted in peak Ir concentration of 423 ppt at the same level in Zumaya, although also demonstrating that the Ir is concentrated in the "yellowish fraction" of the sample (Schmitz et al., 2004). A much larger Ir anomaly (maximum of $2.3 \mathrm{ppb}$ ) occurs near the $\mathrm{P} / \mathrm{E}$ boundary in the Goriska Brda section in Slovenia (Dolenec et al., 2000), although the precise relationship to the CIE has not been established.

A novel potential proxy of impact ejecta is ironrich nanophase material, which was detected at several $\mathrm{K} / \mathrm{T}$ boundary sites and interpreted as a condensate from an impact plume (Wdowiak et al., 2001; Verma et al., 2001). Mössbauer spectroscopy, which is especially sensitive to the presence of the finest grained iron-rich component, was employed in these studies. The discovery of an unusual abundance of magnetite nanoparticles restricted to sediments that coincide with the CIE at one drill site (Lanci et al., 2002) was confirmed at two other drill sites on the 
New Jersey coastal plain and, by analogy with the K/T boundary occurrences, interpreted as an impact plume condensate (Kent et al., 2003a; data are included in the Background Data Set for this paper ${ }^{1}$ ). In this study, magnetic hysteresis was used to detect the nanoparticles, where the ratio of saturation-remanent magnetization to saturation magnetization $\left(M_{\mathrm{sr}} / M_{\mathrm{s}}\right)$ is an effective measure of the overall magnetic grain size distribution. The magnetic properties of magnetite are highly grain size dependent: theoretically, values of $M_{\mathrm{sr}} / M_{\mathrm{s}}$ that approach 0.5 are characteristic of grains over a very narrow size range known as single domain, from about $30 \mathrm{~nm}$ to only about $100 \mathrm{~nm}$, and decrease precipitously to less than 0.1 at smaller and, more pertinently, larger grain sizes (Dunlop and Özdemir, 1997; Newell and Merrill, 2000; Lanci and Kent, 2003). What is so remarkable about the magnetic properties of the CIE sediments on the New Jersey coastal plain is the prevalence of high values close to the theoretical limit of $M_{\mathrm{sr}} / M_{\mathrm{S}}$ (for example, a median $M_{\mathrm{sr}} / M_{\mathrm{s}}$ of 0.42 for 17 samples over nearly $8 \mathrm{~m}$ of CIE sediments in the Clayton core) which are unusual when compared with published values from a wide variety of environments (Kent et al., 2003a,b).

The CIE clastic sediments with anomalously high $M_{\mathrm{sr}} / M_{\mathrm{s}}$ values are enriched in kaolinite, a product of continental weathering. The conundrum is how such a sediment could be produced and transported at the exclusion of normal neritic sedimentary components. We maintain that the abundant magnetic nanoparticles in the CIE interval on the New Jersey coastal plain are best explained as a condensation product of an impact plume, whose unconsolidated ejecta-dust blanket was rapidly weathered into a kaolinite-rich product that was then eroded and redeposited on the adjoining marine shelf, becoming more diluted and mixed with other sediment with distance from the continent.

The possible presence or absence of other evidence for an extraterrestrial impact (e.g., osmium isotopes, helium isotopes, shocked quartz, large crater) is discussed in our earlier papers (Kent et al., 2003a,b).

\subsection{Biological response}

The possibility of an impact trigger for the PETM was dismissed in the first study to recognize the event

\footnotetext{
${ }^{1} \mathrm{http}: / /$ www.elsevier.com/locate/palaeo.
}

due to the "lack of major extinctions in oceanic plankton and in shallow-water benthic communities" (Kennett and Stott, 1991), an expectation clearly influenced by the $\mathrm{K} / \mathrm{T}$ example. However, it has been demonstrated since then that major perturbations did occur to oceanic plankton communities, in shelf environments, and in terrestrial environments during the PETM, in addition to the well-known benthic foraminiferal extinction.

Planktonic foraminifers and calcareous nannoplankton assemblages were severely affected by the PETM. The changes were widespread, abrupt, and indicate up to a nearly complete replacement of the pre-PETM communities (Kelly et al., 1996; Kelly, 2002; Bralower, 2002). At Site 690, where the timing is best constrained, these assemblage changes took place within $<10 \mathrm{k}$.y. following the initial decrease in surface-ocean $\delta^{13} \mathrm{C}$ values. Complementing these changes, a suite of "excursion taxa" evolved closely associated with the onset of the CIE in low- to midlatitude locations (Kelly et al., 1996; Aubry et al., 2000; Aubry and Sanfilippo, 1999; Cramer et al., 1999; Kahn and Aubry, 2004). The changes in community structure are largely transient: the excursion taxa are present only within the interval of low isotopic values, and assemblages return to compositions more similar to pre-PETM conditions during the interval of isotopic recovery. Interestingly, a "topdown" progression of events, the perturbation initially affecting the surface environment and only later the deeper ocean, has been inferred on the basis of planktonic community changes (Kelly, 2002; Bralower, 2002) in addition to geochemical changes (Thomas et al., 2002) which is exactly what we would expect from an impact event.

The perturbation to the deep-ocean environment at the $\mathrm{P} / \mathrm{E}$ boundary led to a major extinction event among benthic foraminifers (35-50\% of species; see Thomas, 1998). Deep-ocean ostracodes also show a perturbation shifting to an assemblage of smaller size and thinner walls (consistent with benthic foraminiferal changes), although there is no associated extinction (Steineck and Thomas, 1996). The dominant factors that have been considered as causing the extinction are decreased oxygenation and increased corrosiveness of deep and intermediate waters, and changes in surface water productivity affecting deepocean nutrient availability (Thomas, 1998). 
The Paleocene/Eocene boundary marks the transition from an "archaic" mammalian assemblage to one dominated by representatives of major modern mammalian groups, such as primates, artiodactyls, and perissodactyls. Although a more detailed analysis may reveal the presence of an extinction "event" in this interval, current analyses suggest that the Paleocene fauna disappeared gradually through the late Paleocene, but that Eocene taxa appeared abruptly at the PETM. Gunnell (1998) shows that the earliest Eocene fauna were substantially different from the Paleocene fauna at the ordinal taxonomic level. The number of modern orders represented in the latest Paleocene is $\sim 12 \%$ of the total assemblage, while immediately following the PETM, it had increased to $\sim 48 \%$. The identification of the CIE in the Bighorn Basin and intensive sampling of this interval has revealed an impressively abrupt change in the mammalian assemblage associated with the onset of the event. In conjunction with major taxonomic changes in the assemblage, Gingerich (2003) documented a distinctive decrease in the size of the fauna; such "dwarfing" is consistent with a major climate perturbation. This analysis shows that the largest pulse in the late Paleocene-early Eocene transition in mammalian fauna, which can be regarded as equally or more important to mammalian evolution as the extinction of the dinosaurs, occurred precisely synchronous with the PETM (Gingerich, 2003; Clyde and Gingerich, 1998).

\section{Global warming and the carbon isotope excursion}

Transient decreases in stable carbon and oxygen isotopic values, now supplemented by $\mathrm{Mg} / \mathrm{Ca}$ ratios, have become central to understanding the PETM. These global perturbations have been documented in numerous geologic sections representing deep-ocean, shallow-marine, and terrestrial environments (Fig. 1). Marine carbonate $\delta^{18} \mathrm{O}$ records, which reflect changes in water temperature and salinity, indicate that temperatures increased throughout the water column. Benthic foraminiferal $\delta^{18} \mathrm{O}$ values decreased by 1.0 $1.8 \%$; a portion of this decrease may be attributable to melting of small ice sheets $(0.2-0.3 \%$ o, e.g., Browning et al., 1996), possibly resulting in a $\sim 20$-m rise in sea level (Speijer and Morsi, 2002), but most of the decrease must be attributed to a deepwater temperature increase of $4-7{ }^{\circ} \mathrm{C}$. Planktonic foraminiferal $\delta^{18} \mathrm{O}$ values show a larger decrease at high latitudes $(\sim 2 \%$ o at Site 690; Kennett and Stott, 1991; Thomas et al., 2002) than at low latitudes $(0.94 \%$ at Site 527 , Thomas et al. (1999); 0.5-0.8\%o at Site 1209, Zachos et al. (2003); <0.4\%o at Site 865; Bralower et al., 1995). A different temperature proxy, the $\mathrm{Mg} / \mathrm{Ca}$ ratio in foraminiferal tests, indicates that the small $\delta^{18} \mathrm{O}$ decrease at low latitudes reflects the counteracting effect of an increase in salinity and a $4-5{ }^{\circ} \mathrm{C}$ temperature increase (Zachos et al., 2003; Tripati and Elderfield, 2004). It is likely that the large $\delta^{18} \mathrm{O}$ decrease at high latitudes and in shallow waters reflects a decrease in salinity together with a temperature increase (e.g., Cramer et al., 1999). The good correspondence between the deep-ocean $\delta^{18} \mathrm{O}$-based estimate and the surface ocean $\mathrm{Mg} / \mathrm{Ca}$-based estimate of the temperature increase indicates that global temperatures increased by $4-5{ }^{\circ} \mathrm{C}$. This implies a $2-8 \times$ increase in atmospheric $p \mathrm{CO}_{2}$ (using the relationship $1.5-4.5{ }^{\circ} \mathrm{C}$ temperature increase per $p \mathrm{CO}_{2}$ doubling; e.g., Houghton et al., 2001; Crowley and Hegerl, 2003) during an interval lasting several tens of thousands of years. Such a rapid increase in $p \mathrm{CO}_{2}$, maintained over several ocean mixing times, must partially reflect a transfer of carbon from the deep ocean to the surface ocean/atmosphere reservoir (producing this increase simply by adding carbon would require the addition of 4500-31,500 Gt $\mathrm{C}$, since the ocean will take up 6.5 times as much carbon as the atmosphere; Siegenthaler and Sarmiento, 1993).

The carbon isotope excursion (CIE) provides evidence for both a large input of carbon to the ocean/ atmosphere reservoir and a transfer of carbon from the deep ocean to the atmosphere/surface ocean reservoir. In the following discussion, we use as a reference the record from Site 690, where the CIE was initially recognized and is still best constrained (Fig. 2; Kennett and Stott, 1991; Bains et al., 1999; Thomas et al., 2002), but our observations are confirmed by data from other locations. We focus on three characteristics of the event that must be explained by a viable model for the PETM:

(1) The initial shift in carbon isotopic values was geologically instantaneous. 

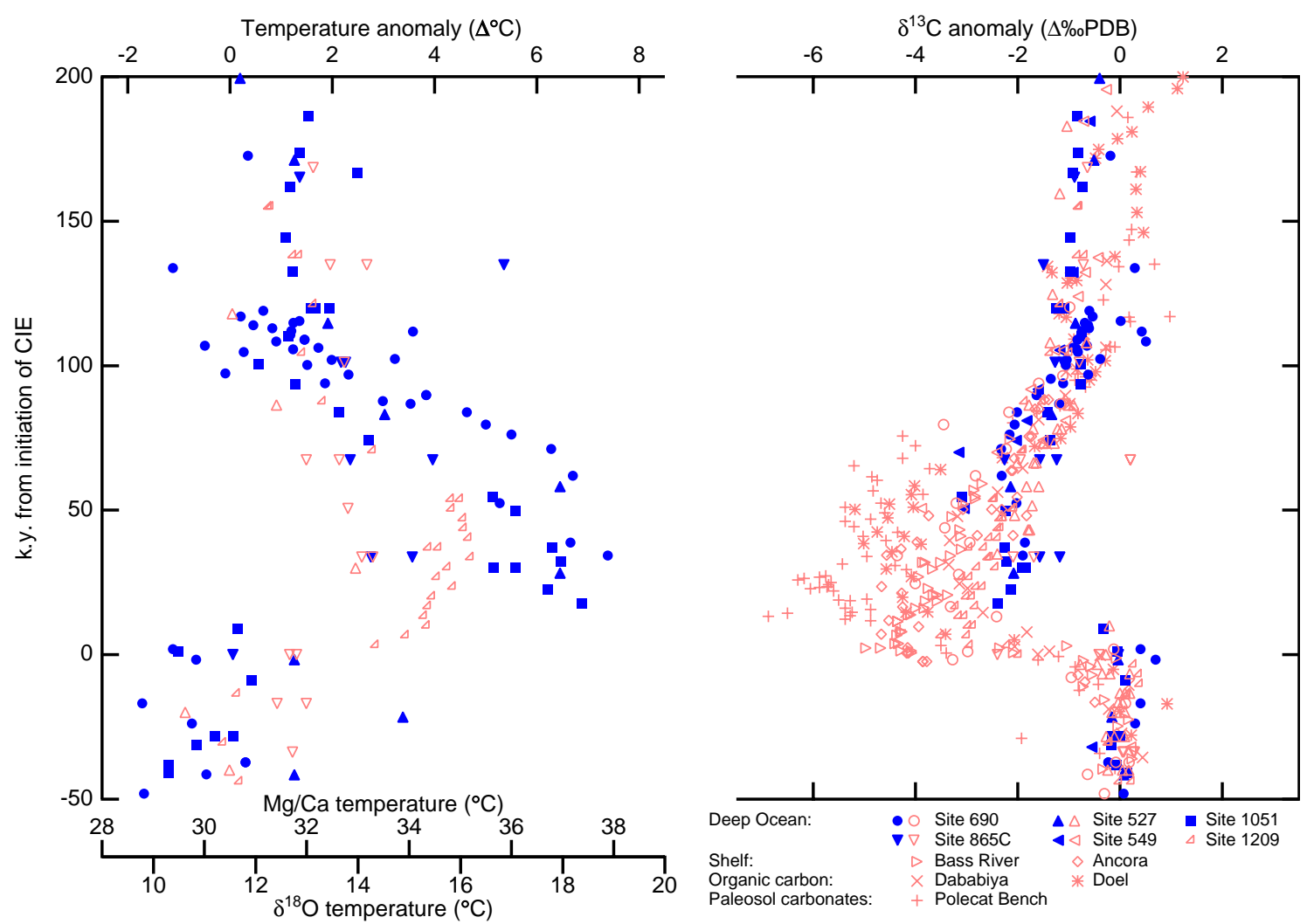

Fig. 1. Compilation of carbon isotope records (right) and temperature proxy records (left) through the PETM. Blue (dark), solid markers are values for intermediate/deep ocean benthic foraminifers, red (light) markers are values for planktonic foraminifers, shelf benthic foraminifers, organic carbon, or paleosol carbonates (e.g., proxies for atmosphere/surface changes). Note that the shift in intermediate/deep ocean $\delta^{13} \mathrm{C}$ values is less than that in grey values, indicating that the atmosphere/surface ocean to deep ocean $\delta^{13} \mathrm{C}$ gradient decreased during the first $\sim 50 \mathrm{k} . \mathrm{y}$. of the PETM. Data plotted are from Polecat Bench, Wyoming, USA (Bowen et al., 2001), Dababiya, Egypt (Dupuis et al., 2003), Doel Borehole, Belgium (Steurbaut et al., 2003), and DSDP/ODP Sites 690 (Kennett and Stott, 1990, 1991; Stott et al., 1990; Thomas and Shackleton, 1996), 527 (Thomas and Shackleton, 1996; Thomas et al., 1999; Tripati and Elderfield, 2004), 1051 (Katz et al., 1999), 865C (Bralower et al., 1995), 549, Bass River (Cramer et al., 1999), and Ancora (unpublished data of B.S. Cramer, see online Background Data Set). Benthic foraminiferal isotope data were corrected to Cibicidoides according to equations given in Katz et al. (2003). In order to show the difference in the magnitude of the $\delta^{13} \mathrm{C}$ decrease, each record was shifted so that pre-CIE values are plotted at $\sim 0 \%$ o. Benthic foraminiferal values were all adjusted by $-1.5 \%$ o. Planktonic foraminiferal, organic carbon, and paleosol carbonate $\delta^{13} \mathrm{C}$ values are not expected to have a consistent offset relative to atmosphere/ surface ocean $\delta^{13} \mathrm{C}$ values, so these records were individually adjusted (planktonic foraminiferal values were adjusted by -2.1 to $-4.1 \%$, organic carbon values were adjusted by $24 \%$, and paleosol carbonate values were adjusted by $9 \%$ ). Paleotemperature estimates were calculated according to the equations in Erez and Luz (1983) for $\delta^{18} \mathrm{O}$ (assuming seawater $\delta^{18} \mathrm{O}=-1.2 \%$; Shackleton and Kennett, 1975) and Tripati and Elderfield (2004) for $\mathrm{Mg} / \mathrm{Ca}$ (assuming seawater $\mathrm{Mg} / \mathrm{Ca}=3.19 \mathrm{~mol} / \mathrm{mol}$ ). Age model for Site 690 is after Farley and Eltgroth (2003); age models for the other records were constructed by aligning the initial decrease in $\delta^{13} \mathrm{C}$ values and the increase in $\delta^{13} \mathrm{C}$ values between $\sim 60$ and $\sim 110 \mathrm{k} . \mathrm{y}$. post-initiation. (For interpretation of the references to colour in this figure legend, the reader is referred to the web version of this article.)

(2) Intermediate/deep-ocean benthic foraminiferal $\delta^{13} \mathrm{C}$ values indicate a $2-3 \%$ decrease while the atmosphere/surface-ocean $\delta^{13} \mathrm{C}$ decrease was $3-5 \%$ o (Fig. 1).

(3) At $\sim 40$ k.y. following the initial bulk sediment $\delta^{13} \mathrm{C}$ shift, surface-dwelling planktonic foraminiferal $\delta^{13} \mathrm{C}$ values increased by $\sim 2 \%$, while benthic foraminiferal, deeper dwelling planktonic foraminiferal, and bulk carbonate $\delta^{13} \mathrm{C}$ values remained low until $\sim 90$ k.y. following the initial isotopic shift (Fig. 2).

These documented features are best discussed in the context of a global carbon cycle box model, in 


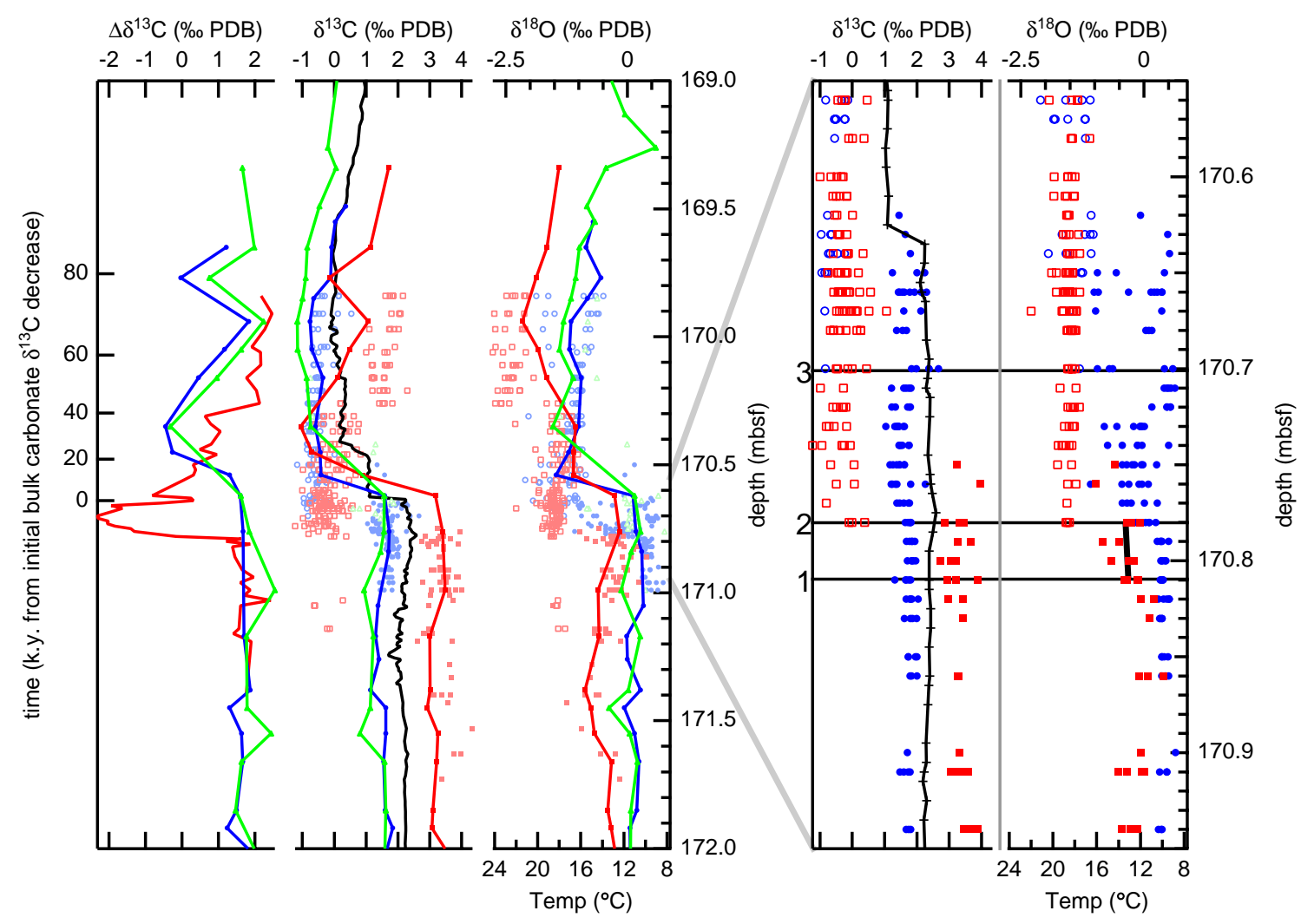

Fig. 2. Carbon and oxygen isotope values through the PETM interval at ODP Site 690. Records are shown for isotopic analyses of bulk carbonate (black line; Bains et al., 1999), analyses of multi-specimen foraminiferal samples (symbols connected by lines; Kennett and Stott, 1991), and analyses of single foraminiferal tests (unconnected symbols; Thomas et al., 2002). Red squares indicate analyses of surface-dwelling planktonic foraminifers (Acarinina), blue circles indicate deep-dwelling foraminifers (Subbotina), and green triangles indicate benthic foraminifers (Nuttalides truempyi). For the single-specimen foraminiferal analyses, open symbols are used for analyses with $\delta^{13} \mathrm{C}$ values $<2.3 \%$ for Acarinina and $<0.6 \%$ of Subbotina (i.e., CIE samples) while filled symbols are used for other analyses (i.e., pre-CIE samples). The left panel also shows the calculated difference between $\delta^{13} \mathrm{C}$ values for surface-dwelling planktonic foraminifers and $\delta^{13} \mathrm{C}$ values for thermocline-dwelling planktonic foraminifers (red line for the median value of single-specimen analyses, blue circles for multi-specimen analyses) or benthic foraminifers (green triangles). The far left axis gives a relative timescale modified after Farley and Eltgroth (2003). Numbered horizontal lines in the right-hand panel are levels identified by Thomas et al. (2002) as (1) the initiation of warming in surface waters, (2) the initial $\delta^{13} \mathrm{C}$ decrease in surface waters, and (3) the initial $\delta^{13} \mathrm{C}$ decrease in deeper waters. We instead believe that level 2 marks the initial perturbation to both $\delta{ }^{13} \mathrm{C}$ and $\delta^{18} \mathrm{O}$ values, with normal variability below that level. It is not clear why the initial shift in isotopic values for Acarinina does not occur at the same level in the Thomas et al. (2002) record as in the record of Kennett and Stott (1991); the former indicates a lag between the initial surface ocean and intermediate ocean changes while the latter indicates synchronous changes. Calculated temperatures are given for $\delta^{18} \mathrm{O}$ analyses using the paleotemperature equation of Erez and Luz (1983) and assuming an ice-free ocean $\delta^{18} \mathrm{O}$ value of $-1.2 \%$ o (Shackleton and Kennett, 1975). (For interpretation of the references to colour in this figure legend, the reader is referred to the web version of this article.)

which estimates of the amount of carbon in various discrete reservoirs combined with estimated fluxes between those reservoirs are used to evaluate mechanisms of perturbation to the carbon cycle (Table 1; see Broecker and Peng, 1982). Carbon is constantly exchanged among the ocean, atmosphere, and terrestrial biomass reservoirs, which we refer to collectively as the exchangeable reservoirs. Carbon that has been sequestered through sedimentary processes (e.g., in fossil fuels, peat, and methane hydrates) and of extraterrestrial origin from comets can potentially be rapidly added to the exchangeable 
Table 1

Exchangeable carbon reservoirs and external resources

\begin{tabular}{|c|c|c|c|c|}
\hline Carbon reservoir & Recent (pre-industrial) & Latest Paleocene & $\begin{array}{l}\text { Normal exchange rate } \\
\text { with atm/ocean }(\mathrm{Gt} / \text { year) }\end{array}$ & $\delta^{13} \mathrm{C}(\mathrm{PDB})$ \\
\hline Atmosphere oceans & $600^{\mathrm{b}}$ & $820^{c}$ & $100^{\mathrm{b}}$ & -6 to $-4^{\mathrm{d}}$ \\
\hline Surface inorganic & $1000^{\mathrm{b}}$ & $1830^{\mathrm{e}}$ & $100^{\mathrm{b}}$ & $2-4^{\mathrm{d}}$ \\
\hline Deep inorganic & $38,000^{\mathrm{b}}$ & $36,000^{\mathrm{e}}$ & $30^{\mathrm{f}}$ & $1-2^{\mathrm{d}}$ \\
\hline Organic & $700^{\mathrm{b}}$ & $850^{\mathrm{e}}$ & $30^{\mathrm{f}}$ & $-17^{\mathrm{g}}$ \\
\hline \multicolumn{5}{|l|}{ Terrestrial biosphere } \\
\hline Land biota & $600^{\mathrm{b}}$ & $1700^{\mathrm{h}}$ & $100^{\mathrm{b}}$ & $-25^{\mathrm{g}}$ \\
\hline Soil and detritus & $1500^{\mathrm{b}}$ & $1200^{\mathrm{h}}$ & $50^{\mathrm{b}}$ & $-25^{\mathrm{g}}$ \\
\hline Total exchangeable & 42,400 & 42,400 & & \\
\hline Coal & $3700^{\mathrm{i}}$ & & & $-25^{\mathrm{j}}$ \\
\hline Oil & $700^{\mathrm{i}}$ & & $0.1-0.4^{\mathrm{k}}$ & -18 to $-34^{\mathrm{j}}$ \\
\hline Gas & $500^{\mathrm{i}}$ & & $0.02-0.07^{\mathrm{k}}$ & -40 to $-70^{\mathrm{j}}$ \\
\hline Peat & $500^{1}$ & up to $15,000^{\mathrm{m}}$ & $0.06^{\mathrm{m}}$ & $-25^{\mathrm{g}}$ \\
\hline Gas hydrates & $500-2500^{1}$ & $200-1100^{1}$ & $0-0.01^{\mathrm{n}}$ & -40 to $-70^{\mathrm{j}}$ \\
\hline Comets & up to $2000^{\circ}$ & up to $2000^{\circ}$ & Sporadic & $-45^{\mathrm{p}} ;-110^{\mathrm{q}}$ \\
\hline
\end{tabular}

\footnotetext{
${ }^{a}$ Estimates are for the present carbon cycle, but should be of similar magnitude in the latest Paleocene.

b Siegenthaler and Sarmiento (1993).

${ }^{c}$ See Royer et al. (2001).

${ }^{\mathrm{d}}$ Assuming a fractionation of $\delta^{13} \mathrm{C}$ values between the atmospheric and surface ocean of $\sim 8$ and that deep-ocean $\delta^{13} \mathrm{C}$ values are $1-2$ less than those in the surface ocean due to oxidation in the deep ocean of organic carbon produced in the surface ocean ("export productivity"; see, e.g., Broecker and Peng, 1982).

${ }^{\mathrm{e}}$ Based on equilibrium calculations using latest Paleocene ocean temperature estimates, $385 \mathrm{ppmv}$ atmospheric $p \mathrm{CO}_{2}$, and assuming that the total exchangeable carbon was the same as today.

${ }^{\mathrm{f}}$ Assuming a $\sim 1000$ year mixing time for the ocean (e.g., Broecker and Peng, 1982).

${ }^{g}$ Photosynthetic fractionation is $\sim-20$, with a difference between marine and terrestrial values due to the fractionation between atmosphere and surface ocean $\mathrm{CO}_{2}$ (e.g., Broecker and Peng, 1982).

${ }^{\mathrm{h}}$ Beerling (2000).

${ }^{\mathrm{i}}$ Houghton et al. (2001).

${ }^{\mathrm{j}}$ Faure (1986).

${ }^{\mathrm{k}}$ Hornafius et al. (1999).

${ }^{1}$ Milkov (2004).

m Kurtz et al. (2003).

${ }^{\mathrm{n}}$ Extrapolation from Milkov and Sassen (2003).

${ }^{\circ}$ Based on a maximum $20 \mathrm{~km}$ diameter with density $1500 \mathrm{~kg} / \mathrm{m}^{3}$ and $25 \% \mathrm{C}$.

${ }^{\mathrm{p}}$ Mean value of IDPs thought to be derived from comets (Messenger, 2000).

${ }^{\mathrm{q}}$ Median value of ground-based determinations for a variety of comets given in Arpigny et al. (2003) and Wyckoff et al. (2000).
}

reservoirs (Table 1). In addition, carbon is constantly added to the exchangeable reservoirs from the mantle and weathering at a rate that is balanced by removal of carbon through sedimentation. Changes in the relative sizes of the exchangeable reservoirs result in variations in the $\delta^{13} \mathrm{C}$ values that will have different magnitudes and directions in different reservoirs. The addition of carbon to the exchangeable reservoirs and altering the net isotopic value of carbon removed from those reservoirs (i.e., by changing the relative rates of organic carbon and carbonate sedimentation) result in $\delta^{13} \mathrm{C}$ variations that are equivalent in magnitude in each of the exchangeable reservoirs.

\subsection{Deep-ocean shift}

Most authors have focused on the $2-3 \%$ decrease in the deep-ocean $\delta^{13} \mathrm{C}$ value, which indicates a major perturbation to the exchangeable carbon cycle. It would take oxidation of all of the estimated late Paleocene biomass (equivalent to $3600 \mathrm{Gt}$ of C) to cause a comparable decrease. Since oxidation of all biomass is clearly unrealistic, the $\delta^{13} \mathrm{C}$ decrease indi- 
cates the addition of a significant amount of carbon from other sources and variations in relative rates of removal, through sedimentation, of organic carbon vs. carbonate carbon.

Methane hydrate has been proposed and is widely accepted as the source of the carbon required to explain the CIE (Dickens et al., 1995; Matsumoto, 1995). Clathrate, a solid composed of water and various gases, but predominantly methane $\left(\mathrm{CH}_{4}\right)$, naturally occurs in marine sediment within a region known as the gas hydrate stability zone (GHSZ). Because of its dependence on temperature and pressure, the GHSZ occupies the upper several hundred meters of sediment where water depth (pressure) is great enough and sediment temperature (increasing with depth in sediment due to the geothermal gradient) is sufficiently cool. Using estimates of bottom-water temperature (derived from $\delta^{18} \mathrm{O}$ analyses on benthic foraminifers) and an assumed geothermal gradient, the configuration and volume of the GHSZ can be approximated for any time in the past (e.g., Dickens, 2001). This exercise leads to the recognition that the $4-8{ }^{\circ} \mathrm{C}$ increase in bottom-water temperature that occurred during the PETM would have significantly reduced the region of stability and would have resulted in areas where the GHSZ completely disappeared, potentially allowing methane from previously stable hydrate to escape into the water column. Recognizing that the $\delta^{13} \mathrm{C}$ value for carbon in methane hydrates is approximately $-60 \%$, the thermal dissociation hypothesis posits that the CIE resulted from $\sim 1700 \mathrm{Gt}$ of carbon from methane that was released when the documented bottom-water temperature increase led to a smaller GHSZ (Dickens et al., 1995).

When this hypothesis was first formulated, it was believed that an "enormous amount of carbon" (7500-15000 Gt) was stored in the form of methane hydrates (Dickens et al., 1995). Under the dubious assumption that a similar quantity of hydrate was uniformly distributed throughout the late Paleocene GHSZ, the $14-19 \%$ of gas hydrate that would have been in this region and the amount of methane hydrate-derived carbon required to account for the magnitude of the CIE seemed to match well (Dickens et al., 1995). This apparent concordance has taken on the status of a tautology among many researchers studying the PETM: methane hydrate is assumed to be the only source of ${ }^{12} \mathrm{C}$-enriched carbon able to account for the magnitude of the CIE (e.g., Zachos et al., 2001; Dickens, 2003), and the logical converse, that the magnitude and shape of the CIE are entirely due to methane hydrate release, is the basis for some interpretation (e.g., Thomas et al., 2002; Bains et al., 1999). The idea that no process other than dissociation of hydrate had any effect on carbon isotope variations during the CIE would require that there were no isotopic effects from the inevitable physical and biological responses to the climate perturbation, which we regard as untenable. The hydrate dissociation hypothesis also begs the question of what caused the extreme warming: any process that would cause a rise in atmospheric $p \mathrm{CO}_{2}$ sufficient to account for the PETM warming would have also resulted in alteration of $\delta^{13} \mathrm{C}$ values, but the thermal dissociation hypothesis predicts that virtually all of the documented warming would have had to precede the $\delta^{13} \mathrm{C}$ decrease in order to melt hydrate (e.g., Katz et al., 2001).

Thermal dissociation may result in release of methane directly to the water column only at relatively shallow water depths where the total GHSZ may be eliminated (Milkov and Sassen, 2003). At greater water depths, the GHSZ becomes thinner but is still present. Pore water within the GHSZ, and especially its upper part near the seafloor, is often undersaturated with gas (Xu and Ruppel, 1999; Milkov et al., 2003), so in regions where the GHSZ is not eliminated, the hydrate-derived gas will migrate upwards into a "new" GHSZ and recrystallize as gas hydrate. Even in regions where the GHSZ is eliminated as a result of warming, gas derived from hydrate is likely to be rapidly oxidized by bacteria and archaea within the sediment and the resulting increase in pore water $\mathrm{CO}_{2}$ will lead to methane-derived carbon being precipitated as carbonate rather than escaping into the ocean. Oxidation of methane released from gas hydrates within the sediment column appears to be very efficient, and the resulting $\mathrm{CO}_{2}$ is readily incorporated in authigenic carbonates which could potentially prevent any of the dissociated methane from reaching the exchangeable carbon reservoirs (Milkov and Sassen, 2003). Since only a portion of hydrate-derived gas is likely to vent from sediments into the water column and atmosphere, and to impact climate change through the global carbon cycle, the hydrate dissociation hypothesis requires the assumption of a very 
large methane hydrate reservoir (Milkov and Sassen, 2003).

The crucial flaw in the hydrate dissociation hypothesis is that the global volume of gas hydrate appears to be an order of magnitude smaller than previously believed. Results from two recent Ocean Drilling Program legs have constrained sediment methane concentrations in passive (Blake Ridge) and active (Hydrate Ridge) margin regions thought to represent areas especially rich in methane. Milkov et al. (2003) extrapolated from the direct measurements in these two areas to arrive at a new estimate of only $1600-2700 \mathrm{Gt}$ of carbon stored in the global methane hydrate reservoir. This is supported by an analysis of all published estimates of the quantity of hydrate, indicating that the amount of carbon is likely to be in a similar range (500-2500 Gt; Milkov, 2004). Due to much higher bottom-water temperatures in the Paleocene, the GHSZ was only $40-50 \%$ of its present volume (Dickens, 2001). Assuming that the distribution of hydrate within this zone was similar to today points to a total late Paleocene hydrate reservoir of only $200-1100 \mathrm{Gt}$ of carbon, of which $\sim 19 \%$ (40$200 \mathrm{Gt}$ of carbon) would have been dissociated in shallow areas where the GHSZ would have entirely disappeared (Milkov et al., 2003; Milkov, 2004), and an even smaller fraction would be expected to enter the exchangeable carbon reservoirs. This implies a rate of methane release of 0.01-0.07 Gt C/year (assuming release over 3000 years, e.g., Katz et al., 2001), which is roughly equivalent to the estimated natural rate of gas seepage from petroleum systems (Table 1; e.g., Milkov and Sassen, 2003) and an order of magnitude less than the estimated rate of methane release from all natural sources at the present day ( $\sim 0.45$ Gt C/year, Houghton et al., 2001). In order to maintain the tautology that only dissociation of methane hydrate can account for the CIE, it has been suggested that this implies either a much higher average sediment hydrate content during the Paleocene or the presence of large amounts of free methane gas below the hydrate stability zone. Modeling results suggest that the average hydrate present within the GHSZ is linearly dependent on the proportion of organic carbon in total sedimentation (Davie and Buffett, 2001); in order to achieve an average hydrate abundance sufficient to account for the CIE through thermal dissociation $(\sim 14 \%$ of pore space filled;
Dickens, 2001) it seems that organic carbon would have had to make up on average $\sim 10 \%$ by weight of total sedimentation in the GHSZ on a global basis, which is unreasonably high. Moreover, the global quantity of free gas underlying the hydrate zone appears to be limited, due to mechanical properties of sediment, to $\ll 1150 \mathrm{Gt}$ carbon for the modern ocean (Hornbach et al., 2004), probably smaller during the Paleocene, and only a portion of this would have been in regions where the overlying GHSZ would have disappeared during the PETM. We conclude that the total contribution from gas hydrates to the decrease in $\delta^{13} \mathrm{C}$ values during the PETM is $\ll 0.3 \%$, which we note is less than the uncertainty in the actual magnitude of the total $\delta^{13} \mathrm{C}$ decrease.

A more likely scenario involves terrestrial carbon stores such as peat. Modern peat deposits include $\sim 500 \mathrm{Gt}$ of carbon with an isotopic composition of approximately $-25 \%$, but the volume of this reservoir may have been more than an order of magnitude larger during the late Paleocene (Table 1; Kurtz et al., 2003). This reservoir represents a sequestration from the rapidly exchangeable carbon cycle, but it is available for oxidation and rapid introduction into the ocean/atmosphere inorganic reservoir as a result of climate change or fire. Kurtz et al. (2003) concluded that terrestrial sequestration of large amounts of organic carbon, likely in the form of peat deposits, was a primary cause of the long-term late Paleocene increase in global $\delta^{13} \mathrm{C}$ (e.g., Shackleton, 1986; Zachos et al., 2001) and suggested that large fires occurring as a result of gradual climate warming and drying during the late Paleocene could account for some or all of the CIE. It would require the oxidation of $\sim 4000 \mathrm{Gt}$ of $\mathrm{C}$ derived from peat $(\sim 25 \%$ of the calculated increase in this reservoir during the late Paleocene) to account for a $2.5 \%$ decrease at the PETM (Kurtz et al., 2003).

A final source of ${ }^{12} \mathrm{C}$-enriched carbon is extraterrestrial: as comets are $20-25 \%$ carbon by weight and have a $\delta^{13} \mathrm{C}$ value of $-45 \%$ or lower (Delsemme, 1988; Jessberger and Kissel, 1991; Jewitt et al., 1997; Messenger, 2000; Wyckoff et al., 2000; Arpigny et al., 2003), the impact of a reasonably large-size comet should result in a decrease in the $\delta^{13} \mathrm{C}$ value of the rapidly exchangeable carbon cycle (Kent et al., 2003a; Bowring et al., 1998; Deming, 1999; Wilde and Quinby-Hunt, 1997). Accounting for a $2.5 \%$ 
decrease in deep-water $\delta^{13} \mathrm{C}$ values in this way would require an extremely, but not impossibly, large comet: assuming cometary density of $1500 \mathrm{~kg} / \mathrm{m}^{3}$, a $20-22-$ $\mathrm{km}$-diameter comet would deliver the requisite $\sim 2200$ Gt of carbon. This seems unlikely since cometary carbon would be added instantaneously to the atmosphere, so that the shift in atmospheric $\delta^{13} \mathrm{C}$ values would be expected to be approximately $-20 \%$, considerably larger than observed. A $\sim 15-\mathrm{km}$-diameter comet would bring with it $\sim 900 \mathrm{Gt}$ of carbon, leading to a $\sim 1 \%$ o decrease in deep-ocean $\delta^{13} \mathrm{C}$ values, while more reasonably sized comets of $10 \mathrm{~km}$ diameter ( $200 \mathrm{Gt}$ carbon) and $5 \mathrm{~km}$ diameter (30 Gt carbon) would result in decreases of only $-0.2 \%$ and $-0.03 \%$ in deep-ocean values, but would still lead to $-4.5 \%$ and $-0.7 \%$ decreases, respectively, in atmosphere/surface ocean values until mixed into the deep ocean. It is quite possible that cometary $\delta^{13} \mathrm{C}$ values are actually much lower than the nominal value of $-45 \%$ o we adopted from measurements on interplanetary dust particles, in which case the isotopic effects might be substantially greater (the median of cometary determinations given in Arpigny et al., 2003, and Wyckoff et al., 2000, is $-110 \%$, but individual determinations have a large error).

Although it has not been generally acknowledged, it is important to note that some portion of the deep-ocean $\delta^{13} \mathrm{C}$ decrease may reflect an alteration in the relative rates of organic carbon and carbonate sedimentation at the onset of the event. The large difference in isotopic value between carbonate and organic carbon means that variations in the relative burial rates of these components can have a fairly rapid effect on the $\delta^{13} \mathrm{C}$ value in the exchangeable reservoirs. Cramer et al. (2003) documented numerous rapid ( $<50$ k.y.) $\delta^{13} \mathrm{C}$ decreases that occurred regularly at eccentricity maxima in the late Paleocene-early Eocene and demonstrated that these events could be explained by variations in the relative proportions of carbonate and organic carbon sedimentation. It therefore must be considered plausible that a similar portion of the CIE (up to $1 \%$ ) may have also resulted from variations in the burial rates of carbonate and organic carbon. If so, then the amount of carbon added to the exchangeable reservoirs necessary to account for the magnitude of the CIE would be reduced by up to $40 \%$.

\subsection{Surface ocean/atmosphere shift}

Benthic foraminiferal isotopic measurements from various locations in the deep ocean indicate that intermediate/deep-ocean $\delta^{13} \mathrm{C}$ values decreased by $2_{-}$ 3\%o during the PETM (Katz et al., 2001; Thomas and Shackleton, 1996; Kennett and Stott, 1991; Bralower et al., 1995) while values reflecting the atmosphere/ surface ocean reservoir show a larger decrease (Fig. 1): $3-4.5 \%$ o for surface-dwelling planktonic foraminifers (Kennett and Stott, 1991; Stott, 1992; Stott et al., 1996; Kelly et al., 1996; Thomas et al., 2002; Zachos et al., 2003), 4-5\%o for shallow-water planktonic and benthic foraminifers (Cramer et al., 1999; Cramer and Wright, unpublished data given here), 3.5-5\% for organic carbon (Steurbaut et al., 2003; Dupuis et al., 2003; Knox et al., 2003), and 6-8\%o for terrestrial paleosol carbonates and mammalian tooth enamel (Bowen et al., 2001; Koch et al., 1992, 1995, 2003). The discrepancy between the magnitude of the shift in these reservoirs indicates that the carbon isotopic gradient between the surface ocean/atmosphere and deep-ocean reservoirs decreased by $1-2 \%$ o during the PETM. The reduction in this gradient is well constrained by foraminiferal isotope records from Site 690 (Fig. 2; Kennett and Stott, 1991), where the carbon isotope value for shallow-dwelling planktonic foraminifers (Acarinina) is $\sim 2 \%$ greater than that for benthic foraminifers prior to the CIE, but is reduced to values similar to (even lower than) benthic and deepdwelling planktonic foraminiferal values for $\sim 40$ k.y. beginning at the onset of the event. Carbon and oxygen isotopic analyses on planktonic foraminifers inferred to have inhabited the thermocline (Subbotina) are close to those of benthic foraminifers, consistent with inferences that the southern ocean was a source of deepwater at this time (Pak and Miller, 1992; Thomas et al., 2003).

The gradient between the $\delta^{13} \mathrm{C}$ values of inorganic carbon in the surface ocean and deep-ocean reservoirs exists as a result of organic carbon produced in the surface water sinking and being oxidized in the deep ocean ("export productivity"). This process is also responsible for an enrichment in inorganic carbon in the deep ocean and a depletion of surface-ocean inorganic carbon and atmospheric $p \mathrm{CO}_{2}$ relative to equilibrium values. The magnitude of the gradient is determined by the relative rates of 
export productivity (the sinking organic matter) and ventilation of the deep ocean. Although input of ${ }^{12} \mathrm{C}$-enriched carbon directly to the atmosphere/surface ocean may have contributed to the initial change in the surface to deep-water $\delta^{13} \mathrm{C}$ gradient (e.g., Thomas et al., 2002), this cannot be the cause of a prolonged interval of reduced gradients: because the residence time of carbon in the surface ocean/atmosphere is $\ll 100$ years, maintenance of a reduced atmosphere/surface ocean $\delta^{13} \mathrm{C}$ value for $\sim 40$ k.y. would require gradually adding $\sim 400$ times the amount of ${ }^{12} \mathrm{C}$-enriched carbon required for an instantaneous shift, which would then be expected to result in a $\delta^{13} \mathrm{C}$ decrease throughout the exchangeable reservoirs $>10$ times the magnitude of the reduction in the surface- to deep-ocean gradient (i.e., a 10-20\%o decrease in the ocean, atmosphere, and biomass). The reduction in the $\delta{ }^{13} \mathrm{C}$ gradient instead reflects a net transfer of carbon from the deep ocean to the atmosphere/surface ocean, as a result of reduced export productivity and/or increased ventilation of the deep ocean. A reduction in export productivity is the most likely mechanism (e.g. Kennett and Stott, 1991; Zachos et al., 1993; Thomas and Shackleton, 1996) as has been invoked for a similar reduction in this gradient at the Cretaceous/Tertiary boundary (D'Hondt et al., 1998; Hsü and McKenzie, 1985; Zachos et al., 1989; Adams et al., 2004). Inferences from $\delta^{13} \mathrm{C}$ values are relevant to changes in global net export productivity and do not preclude an increase in export productivity at individual sites (e.g., Stoll and Bains, 2003; Thomas et al., 2000) or an increased food supply at the seafloor (Thomas, 2003). Reduced surface productivity does appear to be consistent with calcareous nannoplankton (Bralower, 2002) and planktonic foraminiferal (Kelly et al., 1996) community changes. The $\sim 2 \%$ increase in planktonic foraminiferal $\delta^{13} \mathrm{C}$ values $\sim 40$ k.y. after the onset of the CIE at Site 690 (Fig. 2), which is supported by similar increases in other atmosphere/ surface-ocean proxy records (Fig. 1), is therefore significant in that it reestablished the same surface to deep-ocean $\delta^{13} \mathrm{C}$ gradient that existed prior to the CIE. This implies that the oceanic carbon cycle (productivity and circulation patterns) recovered to pre-PETM conditions by $\sim 40$ k.y. after the initial perturbation.

\subsection{Temperature and the initial $\delta^{13} C$ perturbation}

We regard the initiation of the PETM as being a geologically instantaneous event. This is indicated in high-resolution isotopic records from bulk carbonate from several locations, which show a large shift (1$2 \%$ ) between samples taken at centimeter resolution or less (Fig. 3). At all of these sites, sedimentation rates are higher than $1 \mathrm{~cm} / \mathrm{k} . \mathrm{y}$., so that changes that take place in $<1 \mathrm{~cm}$ of sediment must have occurred on timescales of hundreds of years. It is also indicated by four studies involving isotopic analyses on single specimen planktonic foraminifers, which show a bimodal distribution of carbon isotopic values separated by $3-4 \%$ and no intermediate values (level 2 in Figs. 2 and 3; Stott, 1992; Kelly et al., 1996; Thomas et al., 2002; Zachos et al., 2003). Because each foraminiferal test represents less than a single year of growth, if the $3-4 \%$ shift in $\delta^{13} \mathrm{C}$ occurred over an appreciable amount of time, it would be expected that intermediate values would have been measured and these are not observed. The sharp lithologic contact present at many deep-sea sites is also indicative of an extremely rapid onset of the event (Fig. 3); the reduction in surface ocean/atmosphere $\delta^{13} \mathrm{C}$ values may have occurred prior to the lithologic change (e.g., at Site 1209, Fig. 3) but such an offset is consistent with a propagation of changes from the surface to the deep sea. Available data suggest that the onset of the event occurred in $<100$ years, and the available data do not exclude the hypothesis that the initial perturbation occurred in $<1$ year.

It has recently been claimed that isotopic analyses of single foraminiferal tests show a decrease in $\delta^{18} \mathrm{O}$ values beginning prior to the shift in $\delta^{13} \mathrm{C}$ values (Thomas et al., 2002), which would indicate that warming occurred prior to the carbon cycle perturbation and might therefore have triggered this perturbation. We believe that these data support a very different conclusion. A linear regression through the $\delta^{18} \mathrm{O}$ data in the interval that Thomas et al. (2002) claim shows a warming (between levels 1 and 2, Fig. 2) yields an insignificant slope $(0.019 \pm 0.056 \% \mathrm{~cm}$, $1 \sigma$ error), while the mean of all $\delta^{18} \mathrm{O}$ values corresponding to pre-CIE $\delta^{13} \mathrm{C}$ values higher in the section than level 1 (including the two points higher in the section than level 2) is not significantly different from the mean for all points lower in the section 


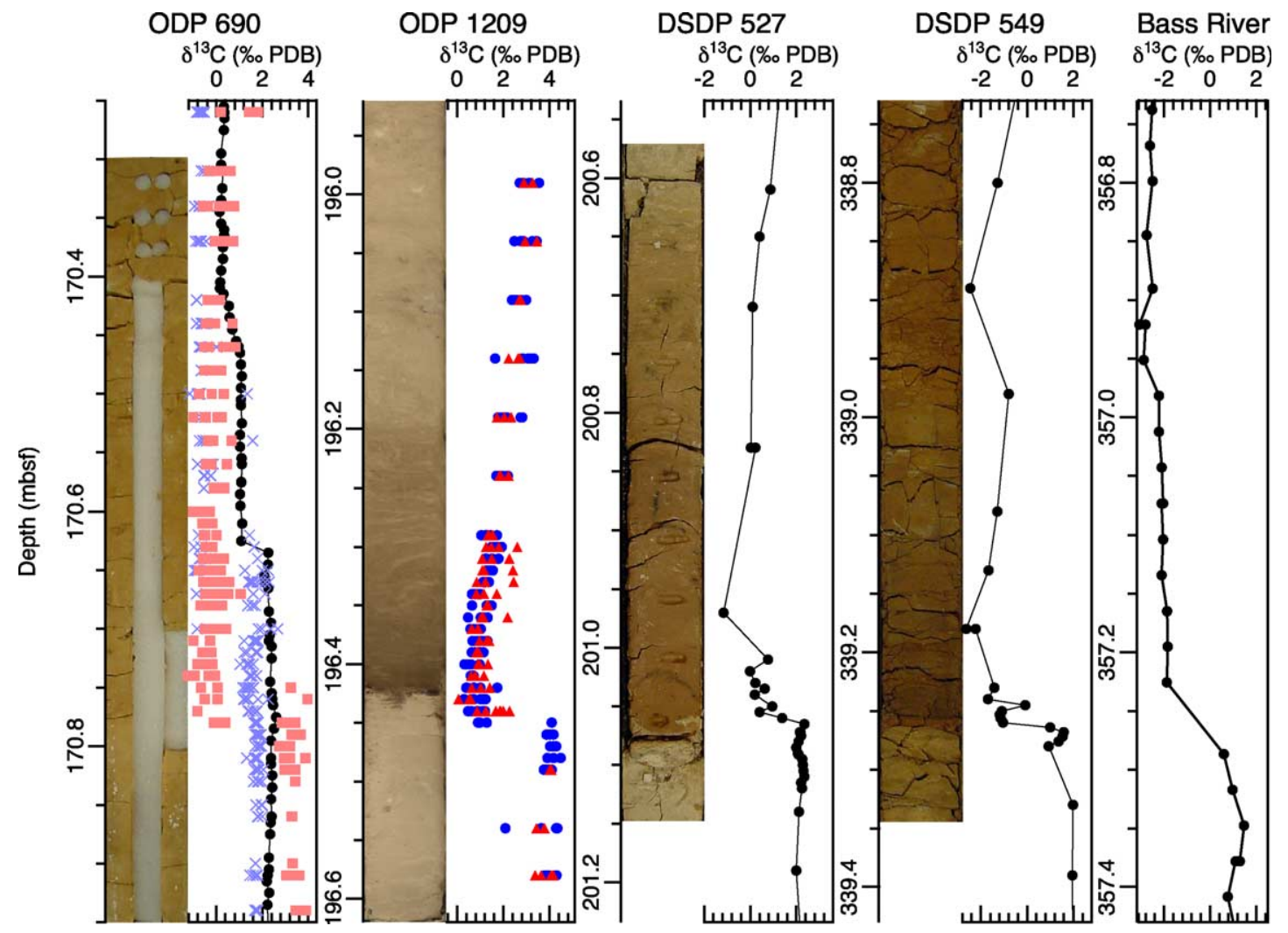

Fig. 3. Carbon isotope records showing abrupt carbon isotope decreases at Sites 690 (Thomas et al., 2002; Bains et al., 1999), 1209 (Zachos et al., 2003), 549 (see Background Data Set), 527 (see Background Data Set), and Bass River (Kent et al., 2003a; see Background Data Set). Core photographs show sharp lithologic contacts at Sites 549, 527, and 1209 nearly coincident with the carbon isotope shifts (Site 1209 photograph courtesy of ODP; other photographs taken for this study). Site 690 is unusual in showing only subtle lithologic changes at the onset of the PETM.

$(-0.45 \pm 0.29 \%$ ovs. $-0.35 \pm 0.36 \%$ o, $1 \sigma$ error $)$. The data therefore indicate that any warming was negligible (in statistical phrasing, the data do not support rejection of the null hypothesis that there was no warming trend prior to the initial change in $\delta^{13} \mathrm{C}$ values). Moreover, we note that the lowest pre-CIE $\delta^{18} \mathrm{O}$ value for an individual planktonic foraminifer is attained during the $\delta^{18} \mathrm{O}$ minimum at $\sim 171.5 \mathrm{mbsf}$, which is not associated with any decrease in $\delta^{13} \mathrm{C}$ values. This value is at the nadir of a $>1 \%$ o decrease in $\delta^{18} \mathrm{O}$ values that begins at $172.14 \mathrm{mbsf}$ (Kennett and Stott, 1991), so if the very minor warming possibly evident at $\sim 170.8$ mbsf was sufficient to trigger the CIE, it would be expected that a much larger $\delta^{13} \mathrm{C}$ decrease should have occurred at $\sim 171.5 \mathrm{mbsf}$. Cramer et al. (2003) showed convincing evidence that deep-ocean temperatures were highly variable in re- sponse to precessional climate forcing during the latest Paleocene-earliest Eocene, with a temperature response at eccentricity maxima of up to $4{ }^{\circ} \mathrm{C}$, but that $\delta^{13} \mathrm{C}$ decreases associated with these temperature increases were much smaller than the CIE. It is therefore unreasonable to attach undue significance to the disputable evidence of warming immediately prior to the CIE. Similar reasoning undermines the claim that warming preceded the $\delta^{13} \mathrm{C}$ perturbation at Sites 865 and 527 (Tripati and Elderfield, 2004). We view the single-specimen planktonic foraminiferal isotopic analyses at Site 690 as strongly supportive of the hypothesis that the carbon cycle perturbation and warming at the PETM were synchronous and occurred geologically instantaneously (although it is not clear why the initial shift in surface-dwelling planktonic foraminiferal isotope values does not occur at the 
same level in the records of Thomas et al., 2002, and Kennett and Stott, 1991). In consideration of plausible mechanisms for rapid warming, it is most likely that the carbon cycle perturbation reflected in the $\delta^{13} \mathrm{C}$ decrease triggered warming as a result of elevated atmospheric $p \mathrm{CO}_{2}$.

Assuming that the initial perturbation affected a pool of 2000-4000 Gt of carbon (surface ocean, atmosphere, and some portion of biomass), the decrease of $\sim 4 \%$ o could be explained by the addition of 320-640 Gt of organic carbon $(-25 \%), 130-270$ Gt of methane hydrate-derived carbon $(-60 \%)$, or $170-360 \mathrm{Gt}$ of cometary carbon $(-45 \% \circ=\sim 10-\mathrm{km}$-diameter comet $)$. Given the magnitude of available sources, these numbers are all plausible. However, the release of methane, oxidation of organic carbon, and collapse of oceanic productivity have the disadvantage of requiring a triggering mechanism, while cometary impact is a viable trigger for all of these as well as being a source of carbon on its own.

Proposed triggers for the release of hydrate are (1) melting in response to rapid changes in ocean circulation resulting from the gradual (59-51 Ma) warming trend (e.g., Zachos et al., 2001, and see Zachos et al., 1993), perhaps aided by volcanism associated with the North Atlantic igneous province (Thomas and Shackleton, 1996) and Caribbean explosive volcanism (Bralower et al., 1997), somehow causing a rapid warming of bottom water; (2) a greenhouse warming feedback mechanism relying on minor warming to release an initial pulse of methane to the atmosphere, resulting in further warming (Thomas et al., 2002); and (3) catastrophic slope failure along the North and South American Atlantic continental margin, presumably oversteepened by several million years of erosion (Katz et al., 2001).

Thermal dissociation (which includes the first two triggers listed above) is not a viable mechanism for releasing $\sim 200 \mathrm{Gt} C$ to the atmosphere. As discussed above, this quantity is equivalent to the total quantity of hydrate-derived carbon that could potentially have been released during equilibration of the sediment geothermal gradient to the peak PETM deep/intermediate ocean temperatures. This equilibration would require $\sim 3000$ years (Katz et al., 2001), but instead, it appears that the increase in deep/intermediate ocean temperatures (at depths where methane hydrate would have existed) lagged the initial carbon cycle perturbation by several thousand years (Thomas et al., 2002). Moreover, thermal dissociation would result in release of methane to the water column above the depth of hydrate stability and an empirical study has shown that in such a case, most of the methane will be dissolved and oxidized in the deep ocean (Rehder et al., 2002), buffering its effect on surface ocean/atmosphere $\delta{ }^{13} \mathrm{C}$ values. Catastrophic slope failure (the third proposed trigger) is a more viable mechanism for rapid addition of carbon from methane hydrates to the atmosphere, since in this case, the methane would be released into the water column below the depth of hydrate stability (e.g., Rehder et al., 2002) and would escape sequestration in authigenic carbonates precipitated within the sediment (Milkov and Sassen, 2003). The $200 \mathrm{Gt}$ of carbon required to account for the full atmosphere/surface-ocean shift is large, however, given that only $\sim 35$ Gt C is present as methane hydrate or gas in the 26,000 $\mathrm{km}^{2}$ area of the Blake Ridge, a region thought to be relatively hydrate rich. Slope failure would have had to occur over an extended area; although Katz et al. (2001) presented evidence that this may in fact have happened, slope failure over such an extended region within a very short $(<1$ k.y.) period would require a high-energy trigger.

The amount of organic carbon required to explain the atmosphere/surface-ocean shift $(\sim 500 \mathrm{Gt})$ is equivalent to $10-20 \%$ of the estimated marine and terrestrial organic carbon reservoir (Table 1), but only $2-4 \%$ of the estimated late Paleocene buildup in longer term terrestrial organic deposits such as peat (Kurtz et al., 2003). There is evidence indicating that extensive fires occurred during the PETM, possibly coincident with the onset of the CIE (Collinson et al., 2003; Kaiho et al., 2003), which might in part reflect burning of large peat deposits (Kurtz et al., 2003). Again, however, the instantaneous nature of the initial atmosphere/surface ocean $\delta^{13} \mathrm{C}$ shift would require a trigger for fires that would have had to cover a significant fraction of the global continental area.

Both the hydrate dissociation and peat burning hypotheses have been presented under the assumption that the several million-years-long warming trend from the late Paleocene to early Eocene was gradual and monotonic. Indeed, most authors have considered that the PETM resulted when this gradual warming 
crossed some "critical threshold" that resulted in a rapid change in Earth's climate state, or as a result of a volcanic perturbation to the otherwise gradually changing climate (e.g., Zachos et al., 1993; Thomas and Shackleton, 1996; Bralower et al., 1997). However, Cramer et al. (2003) demonstrated that Earth's climate and carbon cycle were highly variable throughout the late Paleocene-early Eocene, when numerous episodes similar to the PETM, but of much smaller magnitude, occurred at maxima in Earth's orbital eccentricity. Because episodes of significant insolation-driven climate change did not lead to carbon isotope shifts of the magnitude of the CIE, and insolation-driven climate variations were relatively small at the initiation of the PETM, Cramer et al. (2003) concluded that the closely coupled CIE and PETM must have been triggered by an event external to the normal climate system.

Given the lack of any connection between the timing of the CIE and standard climate forcing mechanisms, the fact that an irresolvably rapid, large initial decrease in $\delta^{13} \mathrm{C}$ values is observed synchronous with an irresolvably rapid, large temperature increase points to an external (to the climate system) trigger for the event. The rate of change exceeded the rate at which parts of Earth's climate that have principally been implicated in causing the event are capable of changing: the rate of ocean circulation limits significant changes in deep-water temperature and the oceanic carbon cycle to timescales of $\sim 1000$ years, while sediment thermal diffusivities limit the time it would take to appreciably warm sediment at depths where significant hydrate occurs to $\sim 2000$ years (Katz et al., 2001), and we believe that an extraterrestrial impact is the only reasonable external trigger. The rapidity and magnitude of the initial climate change at the PETM renders triggering mechanisms involving ocean circulation changes or melting of methane hydrate untenable.

\section{Comet impact scenario for the PETM}

We believe that the large amount of energy involved in a bolide impact is the most plausible explanation for the geologically instantaneous onset of the PETM, but a mechanism must be identified that could plausibly extend the climate perturbation to the carbon cycle for the duration of the PETM. The perturbation to the carbon cycle is indicated both by $\delta^{13} \mathrm{C}$ variations and by globally warmer temperatures, which can only reasonably be explained by an increase in atmospheric $p \mathrm{CO}_{2}$ levels.

We have undertaken a modeling exercise to determine the feasibility of accounting for the PETM as a "bolide summer" resulting from feedbacks following an impact. The model is highly simplified: we have made the assumption that the atmosphere and surface ocean are fully equilibrated on $\sim 100$-year timescales, and that the deep ocean is equilibrated with these reservoirs on $\sim 1000$-year timescales, and the model conditions are calculated only at a few select times post-impact (Table 2, Fig. 4). The model is forced by the addition of quantities of ${ }^{12} \mathrm{C}$-enriched carbon in order to match the $\delta^{13} \mathrm{C}$ trends observed in geologic records. The addition of a large quantity of carbon will initially cause a rise in atmospheric $p \mathrm{CO}_{2}$ and ocean $\sum \mathrm{CO}_{2}$, the latter resulting in a rise in $\left[\mathrm{HCO}_{3}^{-}\right]$ and decrease in $\left[\mathrm{CO}_{3}^{2-}\right]$ in order to maintain charge balance in the oceans. The decrease in $\left[\mathrm{CO}_{3}^{2-}\right]$ during the PETM is reflected in decreased carbonate preservation, resulting in a sharp lithologic contact at many deep sea sites (see Fig. 3). On longer timescales, the decreased carbonate preservation would lead to a buildup of positively charged ions (e.g., $\mathrm{Ca}^{2+}, \mathrm{Mg}^{2+}$ ) in the ocean, eventually leading to removal of the excess $\sum \mathrm{CO}_{2}$ through deposition of excess carbonate (e.g., Broecker and Peng, 1987), which we model by removing quantities of carbon as carbonate (having a surface ocean $\delta^{13} \mathrm{C}$ value) equivalent to the amount added (Table 2). We calculated variations in $\delta^{13} \mathrm{C}$ values, atmospheric $p \mathrm{CO}_{2}$, and ocean $\left[\mathrm{CO}_{3}^{2-}\right]$ (Table 2, Fig. 4) in response to the model forcing. We also calculated the range of temperature increase implied by the calculated increase in atmospheric $p \mathrm{CO}_{2}$ (shaded region in Fig. 4), although for simplicity a $5{ }^{\circ} \mathrm{C}$ temperature increase was imposed in the model. The scenario we present is highly speculative, and we acknowledge that other forcing mechanisms could have been chosen that would be equally consistent with available data, but it is useful to assess the forcing required to account for the PETM in the absence of substantial methane hydrate.

We assume that the event that triggered the PETM was the impact of a $\sim 9$-km-diameter comet, delivering $\sim 150$ Gt of carbon $\delta{ }^{13} \mathrm{C}=-45 \%$ ) directly to the 
Table 2

Modeled variation in the carbon cycle during PETM ${ }^{\mathrm{a}}$

\begin{tabular}{|c|c|c|c|c|c|c|c|c|c|}
\hline \multirow[t]{2}{*}{ Time from impact } & \multirow{2}{*}{$\frac{p \mathrm{CO}_{2}(\mathrm{ppmv})^{\mathrm{b}}}{\mathrm{Atm}^{\mathrm{b}}}$} & \multicolumn{2}{|c|}{$\left[T \mathrm{CO}_{2}\right]\left(\mathrm{mol} / \mathrm{m}^{3}\right)^{\mathrm{b}}$} & \multirow{2}{*}{$\frac{\left[\mathrm{CO}_{3}^{2-}\right]\left(\mathrm{mol} / \mathrm{m}^{3}\right)^{\mathrm{b}}}{\text { Deep }}$} & \multicolumn{3}{|c|}{$\delta^{13} \mathrm{C}(\% \circ \mathrm{PDB})^{\mathrm{b}}$} & \multicolumn{2}{|c|}{$T$ anomaly $^{\mathrm{c}}$} \\
\hline & & Surface & Deep & & Atm & Surface & Deep & Minimum & Maximum \\
\hline Pre-PETM & 386 & 2.18 & 2.45 & 0.078 & -4.5 & 3.5 & 1.5 & -0.0 & -0.0 \\
\hline Impact $(<10$ years $)$ & 456 & 2.18 & 2.45 & 0.078 & -10.8 & 3.5 & 1.5 & 0.4 & 1.1 \\
\hline 100 years & 653 & 2.22 & 2.45 & 0.078 & -9.3 & -1.3 & 1.5 & 1.1 & 3.4 \\
\hline 2000 years & 1266 & 2.31 & 2.48 & 0.060 & -6.9 & 1.1 & 0.3 & 2.6 & 7.7 \\
\hline 20,000 years & 1157 & 2.30 & 2.47 & 0.065 & -7.7 & 0.3 & -0.5 & 2.4 & 7.1 \\
\hline 50,000 years & 386 & 2.18 & 2.45 & 0.078 & -7.1 & 0.9 & -0.9 & 0.0 & 0.0 \\
\hline 120,000 years & 386 & 2.18 & 2.45 & 0.078 & -4.8 & 3.2 & 1.3 & 0.0 & 0.0 \\
\hline
\end{tabular}

\begin{tabular}{|c|c|c|c|c|c|}
\hline \multirow[t]{2}{*}{ Time from impact } & \multicolumn{2}{|l|}{$T\left({ }^{\circ} \mathrm{C}\right)^{\mathrm{d}}$} & \multirow{2}{*}{$\begin{array}{l}\text { Organic input }^{\mathrm{d}} \\
(\mathrm{Gt} \mathrm{C})\end{array}$} & \multirow{2}{*}{$\begin{array}{l}\text { Excess } \mathrm{CaCO}_{3}{ }^{\mathrm{d}} \\
(\mathrm{Gt} \mathrm{C})\end{array}$} & \multirow[t]{2}{*}{ Sources of forcing } \\
\hline & Surface & Deep & & & \\
\hline Pre-PETM & 20 & 12 & 0 & 0 & \\
\hline Impact $(<10$ years $)$ & 20 & 12 & 0 & 0 & input of cometary $\mathrm{C}(150 \mathrm{Gt},-45 \%)$ \\
\hline 100 years & 25 & 12 & 450 & 0 & atmosphere/surface ocean mixing; organic $\mathrm{C}$ input \\
\hline 2000 years & 25 & 17 & 1800 & 0 & deep-ocean mixing; organic $\mathrm{C}$ input; decrease in biopump \\
\hline 20,000 years & 25 & 17 & 1100 & 1500 & organic $\mathrm{C}$ input, $\mathrm{CaCO}_{3}$ compensation \\
\hline 50,000 years & 20 & 12 & 0 & 2000 & recovery of biopump, $\mathrm{CaCO}_{3}$ compensation \\
\hline 120,000 years & 20 & 12 & 0 & 0 & $\delta^{13} \mathrm{C}$ recovery, ocean carbon replacement \\
\hline
\end{tabular}

${ }^{a}$ Formulas and parameters used in the calculations were taken from Toggweiler (1999).

${ }^{\mathrm{b}}$ Calculated model response.

${ }^{\mathrm{c}}$ Estimated response to atmospheric $p \mathrm{CO}_{2}$ variations. Minimum estimate assumes a temperature response of $1.5^{\circ} \mathrm{C} / p \mathrm{CO}_{2}$ doubling, maximum estimate assumes $4.5^{\circ} \mathrm{C} / p \mathrm{CO}_{2}$ doubling.

d Imposed forcing.

atmosphere. This would have instantaneously raised atmospheric $p \mathrm{CO}_{2}$ by $\sim 70$ ppmv and lowered atmospheric $\delta{ }^{13} \mathrm{C}$ by $\sim 7 \%$ o before mixing with the surface ocean. Although we chose to use a large comet in our model, a similar perturbation to atmospheric $p \mathrm{CO}_{2}$ could be obtained with a smaller bolide impact triggering release of terrestrial carbon stores. Effects resulting from a high-energy impact that might release carbon to the atmosphere include (1) superheating of the atmosphere from the shock wave preceding the bolide as well as dispersion of melted material excavated at the site of impact and from the bolide itself, which have been implicated in widespread fires at the K/T boundary (but see Belcher et al., 2003) and could account for fires that have been more firmly documented coincident with the CIE (Collinson et al., 2003; Kaiho et al., 2003); (2) a large tsunami in the event of an oceanic impact, which has been implicated at the $\mathrm{K} / \mathrm{T}$ boundary in slope failures along the North American Atlantic continental margin and widespread turbidite deposits (Norris and Firth, 2002; Olsson et al., 2002) and could account for slope failure at the $\mathrm{P} / \mathrm{E}$ boundary documented along the North American
Atlantic continental margin (Katz et al., 2001), potentially releasing methane and/or hydrocarbon reserves (although we note that there was no whole-ocean $\delta^{13} \mathrm{C}$ decrease at the $\mathrm{K} / \mathrm{T}$ boundary); (3) vaporization of the impactor and target rock (e.g., O'Keefe and Ahrens, 1989); and (4) in the event of an oceanic impact, the initial warming would have been enhanced by rapid venting of much of the excess deep-ocean $\mathrm{CO}_{2}$ to the atmosphere and enhanced atmospheric $\mathrm{H}_{2} \mathrm{O}$. In fact, our choice of a large comet minimizes the initial perturbation to the carbon cycle: reducing the size of the comet, or assuming a non-carbon-rich bolide, would force us to add more carbon from a less ${ }^{12} \mathrm{C}$ enriched source in order to account for the initial decrease in $\delta^{13} \mathrm{C}$ values.

In order to produce a $\sim 5 \%$ o decrease in surface ocean/atmosphere $\delta^{13} \mathrm{C}$ values, we added an additional $\sim 450 \mathrm{Gt}$ of organic carbon $\left(\delta^{13} \mathrm{C}=-25 \%\right.$ o $)$ to the atmosphere and surface ocean within $\sim 100$ years following the impact. This additional carbon could have come from burning (either impact-induced or as a result of impact-induced climate warming) of terrestrial biomass and organic-rich deposits, re- 


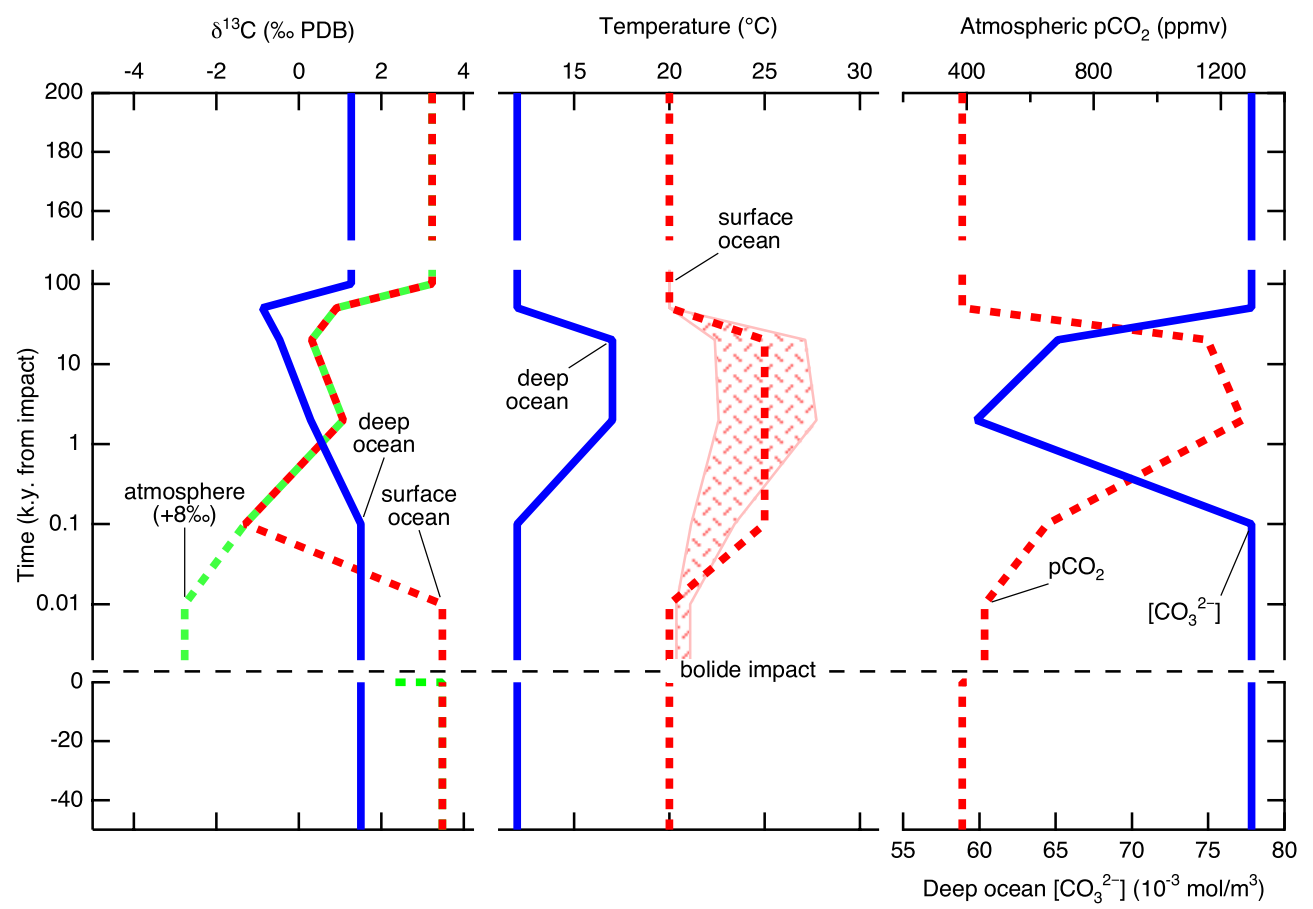

Fig. 4. Schematic diagram of climate and carbon cycle effects during the PETM, according to the model in Table 2. In the temperature plot, lines show the imposed model forcing, while the shaded region indicates the expected response from the $p \mathrm{CO}_{2}$ variations resulting from the model, based on an assumption of $1.5-4.5^{\circ} \mathrm{C}$ temperature increase per $p \mathrm{CO}_{2}$ doubling. Note that the timescale for the central portion of the plot is expanded and plotted on a logarithmic scale.

duced productivity/reduction in the biological pump (thereby retaining $\mathrm{CO}_{2}$ in the surface ocean/atmosphere that would otherwise have been transported to the deep ocean as organic carbon or sequestered in terrestrial biomass), and/or release of methane or hydrocarbon reserves as a result of slumping along continental margins. Although sources such as methane hydrate are substantially more enriched in ${ }^{12} \mathrm{C}$ than organic carbon, it is likely that carbon from sources less ${ }^{12} \mathrm{C}$ enriched (deep-ocean $\sum \mathrm{CO}_{2}$, carbonate sediments) would have been released. We regard the amount of carbon added in our model as a conservative estimate of the amount that must have been added to account for the surface-ocean/ atmospheric $\delta^{13} \mathrm{C}$ decrease. Most realistic changes in the assumptions (e.g., using a smaller or non-carbon-rich bolide) would require a larger input of carbon to account for the $\delta^{13} \mathrm{C}$ decrease, and it is likely that a substantial amount of isotopically "neutral" carbon would have been released at the time of impact. In the scenario, we present atmo- spheric $p \mathrm{CO}_{2}$ increases by an additional $\sim 195 \mathrm{ppmv}$ (to $\sim 265$ ppmv above pre-impact conditions) both as a direct result of added carbon and indirectly due to reduced solubility of $\mathrm{CO}_{2}$ in warmer surface ocean waters $(\sim 15 \mathrm{ppmv})$. The increase in atmospheric $p \mathrm{CO}_{2}$ in this scenario would not appear to be sufficient to account for a $\sim 5{ }^{\circ} \mathrm{C}$ increase in surface temperatures (as indicated by the $\delta^{18} \mathrm{O}$ data from Site 690), suggesting that the net $\delta^{13} \mathrm{C}$ value of the carbon added was more positive than the organic carbon source we assume.

Benthic foraminiferal isotope records have been unable to capture the shape of the decrease in deep/ intermediate ocean $\delta{ }^{13} \mathrm{C}$ values. At Site 690, two different inferences can be made on the basis of isotopic analyses of Subbotina, a deep-dwelling planktonic foraminifer, and bulk carbonate, which is primarily made up of deep-dwelling calcareous nannofossils. Subbotina $\delta^{13} \mathrm{C}$ values at 690 are similar to those of benthic foraminifers prior to the event, but diverge from the benthic records during 
the recovery from the event; these indicate an abrupt decrease in $\delta^{13} \mathrm{C}$ values by $2 \%$ with only a minor subsequent decrease (Fig. 2). The bulk carbonate $\delta{ }^{13} \mathrm{C}$ values are consistently offset from those of benthic foraminifers by $\sim 1 \%$ o throughout the event and show a series of decreases, with an initial abrupt $\sim 1.2 \%$ decrease followed by a further $\sim 1.2 \%$ over $\sim 60$ k.y., most of which occurred at $\sim 20$ k.y. following the initiation of the event. We assume that the shape of the bulk carbonate record mimics that of deep-ocean $\delta^{13} \mathrm{C}$ during the interval of this decrease, as it does in the portion of the record where benthic foraminiferal $\delta^{13} \mathrm{C}$ values are available. In our speculative model, we therefore add $1800 \mathrm{Gt}$ of carbon with an organic carbon $\delta{ }^{13} \mathrm{C}$ signature to the ocean/atmosphere within 2000 years following the bolide impact, during which time the initial perturbation to the surface ocean/atmosphere would have been mixed into the deep ocean. In addition, we assume that reduced export productivity relative to pre-PETM conditions (a $60 \%$ reduction in our model) resulted in a $\sim 1.2 \%$ o reduction in the surface- to deep-ocean $\delta^{13} \mathrm{C}$ gradient. The reduction in the biological pump (54 ppmv) and reduced solubility of $\mathrm{CO}_{2}$ in the warmer deep ocean (65 ppmv) contribute to a rise in atmospheric $p \mathrm{CO}_{2}$, but more significantly, these processes result in the bulk of the added carbon pooling in the atmosphere, in total raising $p \mathrm{CO}_{2}$ by an additional $\sim 615$ ppmv to $\sim 1270$ ppmv. This level $\left(\sim 3.3 \times\right.$ pre-PETM $\left.p \mathrm{CO}_{2}\right)$ is sufficient to account for a $3-9{ }^{\circ} \mathrm{C}$ increase in global surface temperatures (Houghton et al., 2001; Crowley and Hegerl, 2003).

We call on an additional $1100 \mathrm{Gt}$ of carbon from an organic source over the subsequent 20 k.y. and removal of $1500 \mathrm{Gt}$ of carbon through carbonate sedimentation. The combined effect is to further decrease deep-ocean $\delta^{13} \mathrm{C}$ values to $2 \%$ less than prePETM values, with a slight decline in atmospheric $p \mathrm{CO}_{2}$ since more carbon is removed than is added. Although no ${ }^{12} \mathrm{C}$-enriched carbon is added between 20 and 50 k.y. following the impact, deep-ocean $\delta^{13} \mathrm{C}$ values continue to decrease as a result of excess carbonate sedimentation, removing $2000 \mathrm{Gt}$ of carbon to bring the atmosphere/ocean carbon reservoir back to its pre-impact size. Removal of carbon combined with recovery of the biological pump results in a rapid decrease in atmospheric $p \mathrm{CO}_{2}$ levels to nearly
pre-PETM levels, which should have resulted in a temperature decrease. Surface ocean $\delta^{13} \mathrm{C}$ values increase as a result of the recovery of the biological pump while deep-ocean $\delta^{13} \mathrm{C}$ values continue to decline due to excess carbonate sedimentation, which we assume has a surface ocean $\delta^{13} \mathrm{C}$ value and is therefore less ${ }^{12} \mathrm{C}$-enriched than the mean ocean. Recovery of $\delta^{13} \mathrm{C}$ values to pre-PETM conditions occurs by $\sim 120$ k.y. as a result of the constant cycling of carbon through the ocean.

Our scenario makes the following predictions: (1) a total input of $3500 \mathrm{Gt} \mathrm{C}$, which in combination with a reduction in the biological pump would have driven a fourfold increase in atmospheric $p \mathrm{CO}_{2}$; (2) the temperature increase must have occurred primarily as a result of the perturbation to the carbon cycle, but because the bulk of additional carbon would have been input to the atmosphere (through oxidation of organic carbon stores), it is not expected that the lag could be observed in the geologic record, except possibly in highly expanded sections; (3) carbonate compensation offsetting the addition of carbon would have led to a relatively stable warm climate through several tens of thousands of years prior to recovery of the biological pump; (4) perturbations to the deep-water environment, including the benthic foraminiferal extinction, should have occurred in the first few thousand years following impact, in conjunction with lithologic changes related to carbonate dissolution. It is worth noting that the larger amount of carbon added in our scenario predicts a greater decrease in ocean sediment carbonate content than that predicted by the hydrate dissociation hypothesis.

In this model, the important role of the reduction in the biological pump is highlighted: although the ocean carbonate system would be expected to compensate for the addition of excess carbon on 10 k.y. timescales (Broecker and Peng, 1987), atmospheric $p \mathrm{CO}_{2}$ would have remained high until recovery of organic carbon export to the deep ocean. There is good evidence that a reduction in the biological pump occurred - the reduction in the surface-to-deep ocean $\delta{ }^{13} \mathrm{C}$ gradient - but the mechanism for this reduction is unclear. In seeking to explain a similar reduction following the $\mathrm{K} / \mathrm{T}$ impact event, Hsü and McKenzie (1985) called on a "Strangelove ocean" with very 
reduced productivity, but D'Hondt et al. (1998) pointed out that such a productivity crash would only be expected during a very brief initial period of high atmospheric dust and reduced sunlight. Instead, D'Hondt et al. (1998) proposed that there was an increase in the proportion of organic production reconverted to inorganic form in the surface waters. In our model, we used a $\sim 60 \%$ reduction in the biological pump; as pointed out by D'Hondt et al. (1998), this could be effected by an increase in the efficiency of surface-ocean organic carbon degradation from $90 \%$ to $97 \%$, an effect that might be difficult to discern in proxy data.

Finally, we recognize that our model requires the input of a large amount of organic carbon and therefore relies heavily on the hypothesis of Kurtz et al. (2003) that terrestrial deposits of peat were much larger in the late Paleocene than today and could have been rapidly released during the PETM by wildfires occurring during a much warmer climate. In some sense, this hypothesis is similar to the invocation of a much larger hydrate reservoir during the late Paleocene, but Kurtz et al. (2003) have presented good arguments for excess terrestrial sequestration of $15,000 \mathrm{Gt}$ of carbon during the late Paleocene, supported by their analysis of carbon and sulfur isotope data as well as known late Paleocene coal reserves, whereas warmer bottom-water temperatures require a smaller gas hydrate stability zone and no evidence has been presented that would indicate a larger methane hydrate reservoir than today. If Cramer et al. (2003) are correct in ascribing orbitally forced decreases in $\delta^{13} \mathrm{C}$ values of up to $1 \%$ to variations in the relative deposition rates of carbonate vs. organic carbon, and if the same response was triggered at the PETM, then the amount of added carbon might have been half as much as we propose. However, this would imply a smaller increase in atmospheric $p \mathrm{CO}_{2}$ levels and require that the global temperature sensitivity to $p \mathrm{CO}_{2}$ levels was at the high end of the quoted range, rather than in the middle (Fig. 4).

\section{Summary}

While extraterrestrial impact has received serious consideration as the trigger for "instantaneous" en- vironmental perturbations at other geologic boundaries, the possibility of an impact trigger for the PETM has received very little attention. Instead, most authors have focused on the magnitude of the $\delta^{13} \mathrm{C}$ decrease and the hypothesis that this resulted from dissociation of methane hydrates. However, analyses now show that the methane hydrate reservoir was unlikely to have been large enough to account for the carbon isotopic perturbation, and that physical limitations to the rate at which thermal dissociation of hydrate could occur make it an implausible mechanism to account for the extremely rapid initial decrease in $\delta^{13} \mathrm{C}$ values, especially given the evidence for stable pre-CIE temperatures at intermediate water depths where hydrate would have existed. Furthermore, methane hydrate as a sole source for the CIE cannot explain the extreme variations in climate and ecological perturbations that occurred: the very low $\delta^{13} \mathrm{C}$ value of methane hydrate minimizes the amount of carbon needed to account for the CIE, while the thermal dissociation mechanism requires that the documented warming preceded and was independent of the perturbation to the carbon cycle. It is more reasonable to assume that the $4-5{ }^{\circ} \mathrm{C}$ temperature increase resulted from the perturbation to the carbon cycle that is reflected in the decrease in $\delta^{13} \mathrm{C}$ values.

The instantaneous onset of the PETM, the topdown progression of environmental changes in the oceans, and the extreme perturbations to the surface environment are all consistent with a bolide impact. There is already tantalizing independent evidence that an impact occurred at the time of the PETM and the "bolide summer" hypothesis makes specific predictions that should motivate further investigations: we expect (1) normal climate variability prior to an abrupt onset of the event; (2) tracers of an impact corresponding to the abrupt initial climate perturbation; (3) a much larger decrease in carbonate preservation than that predicted by the hydrate dissociation hypothesis; (4) evidence for widespread terrestrial fires as a source of carbon; (5) a global net reduction in export productivity. To our knowledge, none of these predictions has been disproven, while some of them are supported by available data. Researchers involved in studies of the $\mathrm{P} / \mathrm{E}$ boundary should consider whether their data 
are consistent with the idea of an impact trigger for the event. ${ }^{2}$

Although there are no mass extinctions among planktonic organisms at the PETM, in contrast to the $\mathrm{K} / \mathrm{T}$ boundary, we take the perspective that this more likely resulted from a difference in severity and character of perturbations to the surface environment rather than a difference in the ultimate cause of the changes. The perturbation in the surface-ocean environment at the $\mathrm{K} / \mathrm{T}$ boundary was severe enough that pre-existing species were unable to maintain any ecological niche during the aftermath; as a result, the post-perturbation community was made up of the few survivors and newly evolved species. At the $\mathrm{P} / \mathrm{E}$ boundary, pre-existing species were able to maintain viable populations in refugia, although at many sites they were temporarily absent or greatly reduced in abundance. The transient nature of these changes should be interesting from an evolutionary perspective: the $\mathrm{P} / \mathrm{E}$ boundary may represent an event nearly serious enough to cause a global mass extinction, but the severity of the kill mechanisms fell somewhat short, allowing pre-existing communities to become reestablished and diversify following the climatic perturbation. In contrast, the major changes in ocean carbonate chemistry and export productivity evidently did lead to the mass extinction among benthic foraminifers at the $\mathrm{P} / \mathrm{E}$ boundary.

In conclusion, we invoke a (cometary) bolide impact to explain the established extremely rapid

\footnotetext{
${ }^{2}$ During final revision of this manuscript, an alternative hypothesis was published that may be able to explain the initial, rapid decrease in $\delta^{13} \mathrm{C}$ values at the onset of the CIE as the result of emplacement of basaltic sills in the northeast Atlantic (Svensen et al., 2004). Heating of organic-rich sediment surrounding the sills would result in the generation of large amounts of thermogenic methane (note that this is not hydrate-sourced methane); if sill emplacement and subsequent methane production was extremely rapid, then enough methane could potentially have been vented to the atmosphere to explain the initial atmosphere/surface ocean $\delta^{13} \mathrm{C}$ decrease. While this hypothesis merits further investigation, we note that it does not obviously provide an explanation for the Ir and MNP anomalies and that the large amount of energy released virtually instantaneously in a bolide impact seems more consistent with the perturbation to surface marine biota documented synchronous with the extremely rapid initial decrease in $\delta^{13} \mathrm{C}$ values. In any case, we believe that a carbon cycling scenario similar to the one we outline would still be necessary to explain the full event.
}

surface environment warming and carbon cycle perturbation at the onset of the PETM. We believe that this initial warming would have led to widespread burning of terrestrial peat deposits, as hypothesized by Kurtz et al. (2003), producing an extended period of high atmospheric $p \mathrm{CO}_{2}$ and the warm climate of the PETM. The already extremely detailed documentation of the PETM may provide an excellent opportunity to examine the environmental and biological perturbation and recovery following a bolide impact.

\section{Acknowledgements}

We are grateful to A.V. Milkov, M.E. Katz, K.G. Miller, and the reviewers F.T. Kyte, D.J. Thomas, and F. Maurrasse for providing useful criticism that greatly improved this manuscript. We thank M.A. Lamolda and the organizing committee for the "Bioevents" meeting in Caravaca for giving us a reason to write this. J.D. Wright kindly allowed access to the Rutgers Stable Isotope Laboratory for bulk sediment analysis at DSDP Sites 517 and 549, and D.J. Thomas graciously provided data tables for ODP Site 690 isotope analyses. This work was supported under a Japan Society for the Promotion of Science Postdoctoral Fellowship for Foreign Researchers (Cramer) and grant OCE0084032 (Biocomplexity) from the U.S. National Science Foundation (Kent). LDEO 6636.

\section{References}

Adams, J., Mann, M., D’Hondt, S., 2004. The Cretaceous-Tertiary extinction: modeling carbon flux and ecological response. Paleoceanography 19, PA1002.

Arpigny, C., Jehin, E., Manfroid, J., Hutsemékers, D., Schulz, R., Stüwe, J., Zucconi, J.-M., Ilyin, I., 2003. Anomalous nitrogen isotope ratios in comets. Science 301, 1522-1524.

Aubry, M.-P., Sanfilippo, A., 1999. Late Paleocene-early Eocene sedimentary history in western Cuba: implications for the LPTM and for regional tectonic history. Micropaleontology 45, 5-18.

Aubry, M.-P., Cramer, B., Miller, K., Wright, J., Kent, D., Olsson, R., 2000. Late Paleocene event chronology: unconformities, not diachrony. Bulletin de la Société Géologique de France 171, 367-378.

Bains, S., Corfield, R., Norris, R., 1999. Mechanisms of climate warming at the end of the Paleocene. Science 285, 724-727. 
Beerling, D., 2000. Increased terrestrial carbon storage across the Palaeocene-Eocene boundary. Palaeogeography, Palaeoclimatology, Palaeoecology 161 (3-4), 395-405.

Belcher, C., Collinson, M., Sweet, A., Hildebrand, A., Scott, A., 2003. Fireball passes and nothing burns - the role of thermal radiation in the cretaceous-tertiary event: evidence from the charcoal record of North America. Geology 31, $1061-1064$.

Bowen, G., Koch, P., Gingerich, P., Norris, R., Bains, S., Corfield, R., 2001. Refined isotope stratigraphy across the continental Paleocene-Eocene boundary on Polecat Bench in the northern Bighorn Basin. In: Gingerich, P. (Ed.), PaleoceneEocene stratigraphy and biotic change in the Bighorn and Clarks Fork Basins, Wyoming. Papers on Paleontology 33. Museum of Paleontology, The University of Michigan, Ann Arbor, pp. 73-88.

Bowring, S., Erwin, D., Jin, Y., Martin, M., Davidek, K., Wang, W., 1998. U/Pb zircon geochronology and tempo of the end-Permian mass extinction. Science 280, 1039-1045.

Bralower, T., 2002. Evidence of surface water oligotrophy during the Paleocene-Eocene thermal maximum: nannofossil assemblage data from Ocean Drilling Program Site 690, Maud Rise, Weddell Sea. Paleoceanography 17 (2), 1023.

Bralower, T., Zachos, J., Thomas, E., Parrow, M., Paull, C., Kelly, D., Premoli Silva, I., Sliter, W., Lohmann, K., 1995. Late Paleocene to Eocene paleoceanography of the equatorial Pacific Ocean: Stable isotopes recorded at Ocean Drilling Program Site 865, Allison Guyot. Paleoceanography 10, 841-865.

Bralower, T., Thomas, D., Zachos, J., Hirschmann, M., Röhl, U., Sigurdsson, H., Thomas, E., Whitney, D., 1997. High-resolution records of the late Paleocene thermal maximum and circum-Caribbean volcanism: is there a causal link? Geology $25,963-966$.

Broecker, W., Peng, T.-H., 1982. Tracers in the Sea. Lamont-Doherty Geological Observatory, Palisades, NY.

Broecker, W., Peng, T.-H., 1987. The role of $\mathrm{CaCO}_{3}$ compensation in the glacial to interglacial atmospheric $\mathrm{CO}_{2}$ change. Global Biogeochemical Cycles 1, 15-29.

Browning, J., Miller, K., Pak, D., 1996. Global implications of lower to middle Eocene sequence boundaries on the New Jersey coastal plain: the icehouse cometh. Geology 24, 639-642.

Clyde, W., Gingerich, P., 1998. Mammalian community response to the latest Paleocene thermal maximum: an isotaphonomic study in the northern Bighorn Basin, Wyoming. Geology 26, $1011-1014$.

Collinson, M., Hooker, J., Gröcke, D., 2003. Cobham lignite bed and penecontemporaneous macrofloras of southern england: a record of vegetation and fire across the Paleocene-Eocene thermal maximum. In: Wing, S., Gingerich, P., Schmitz, B., Thomas, E. (Eds.), Causes and Consequences of Globally Warm Climates in the Early Paleogene, Special Paper, vol. 369. Geological Society of America, Boulder, CO, pp. 333-350.

Cramer, B., Aubry, M.-P., Miller, K., Olsson, R., Wright, J., Kent, D., 1999. An exceptional chronologic, isotopic, and clay mineralogic record of the latest Paleocene thermal maximum, Bass River, NJ, ODP 174AX. Bulletin de la Société Géologique de France 170, 883-897.
Cramer, B., Wright, J., Kent, D., Aubry, M.-P., 2003. Orbital climate forcing of $\delta^{13} \mathrm{C}$ excursions in the late Paleocene-early Eocene (Chrons C24n-C25n). Paleoceanography 18 (4), 1097.

Crowley, T., Hegerl, G., 2003. Estimating climate sensitivity from paleo-data. Eos Transactions AGU 84 (46), PP22B-08.

Davie, M., Buffett, B., 2001. A numerical model for the formation of gas hydrate below the seafloor. Journal of Geophysical Research 106, 497-514.

Delsemme, A., 1988. The chemistry of comets. Philosophical Transactions of the Royal Society of London A325, 509-523.

Deming, D., 1999. On the possible influence of extraterrestrial volatiles on Earth's climate and the origin of the oceans. Palaeogeography, Palaeoclimatology, Palaeoecology 146, 33-51.

D'Hondt, S., Donaghay, P., Zachos, J., Luttenberg, D., Lindinger, M., 1998. Organic carbon fluxes and ecological recovery from the Cretaceous-Tertiary mass extinction. Science 282, $276-279$.

Dickens, G., 2001. The potential volume of oceanic methane hydrates with variable external conditions. Organic Geochemistry $32,1179-1193$.

Dickens, G., 2003. Rethinking the global carbon cycle with a large, dynamic and microbially mediated gas hydrate capacitor. Earth and Planetary Science Letters 213, 169-183.

Dickens, G., O’Neil, J., Rea, D., Owen, R., 1995. Dissociation of oceanic methane hydrate as a cause of the carbon isotope excursion at the end of the Paleocene. Paleoceanography 10, 965-971.

Dolenec, T., Pavšič, J., Lojen, S., 2000. Ir anomalies and other elemental markers near the Palaeocene-Eocene boundary in a flysch sequence from the Western Tethys (Slovenia). Terra Nova 12, 199-204.

Dunlop, D., Özdemir, Ö., 1997. Rock Magnetism. Cambridge University Press, Cambridge.

Dupuis, C., Aubry, M.-P., Steurbaut, E., Berggren, W., Ouda, K., Magioncalda, R., Cramer, B., Kent, D., Speijer, R., HeilmannClausen, C., 2003. The Dababiya Quarry section: Lithostratigraphy, clay mineralogy, geochemistry, and paleontology. Micropaleontology 49 (Suppl. 1), 41-59.

Erez, J., Luz, B., 1983. Experimental paleotemperature equation for planktonic foraminifera. Geochimica et Cosmochimica Acta 47, $1025-1031$.

Farley, K., Eltgroth, S., 2003. An alternative age model for the Paleocene-Eocene thermal maximum using extraterrestrial ${ }^{3} \mathrm{He}$. Earth and Planetary Science Letters 208, 135-148.

Faure, G., 1986. Principles of Isotope Geology, 2nd ed. John Wiley and Sons, New York.

Gingerich, P., 2003. Mammalian responses to climate change at the Paleocene-Eocene boundary: Polecat Bench record in the northern Bighorn Basin, Wyoming. In: Wing, S., Gingerich, P., Schmitz, B., Thomas, E. (Eds.), Causes and Consequences of Globally Warm Climates in the Early Paleogene, Special Paper, vol. 369. Geological Society of America, Boulder, CO, pp. $463-478$.

Gunnell, G., 1998. Mammalian faunal composition and the Paleocene/Eocene Epoch/Series Boundary: evidence from the northern Bighorn Basin, Wyoming. In: Aubry, M.-P., Lucas, S., Berggren, W. (Eds.), Late Paleocene-Early Eocene Climatic 
and Biotic Events in the Marine and Terrestrial Records. Columbia University Press, New York, pp. 409-427.

Hornafius, J., Quigley, D., Luyendyk, B., 1999. The world's most spectacular marine hydrocarbon seeps (Coal Oil Point, Santa Barbara Channel, California): Quantification of emissions. Journal of Geophysical Research 104 (C9), 20703-20711.

Hornbach, M., Saffer, D., Holbrook, W., 2004. Critically pressured free-gas reservoirs below gas-hydrate provinces. Nature 427, $142-144$.

Houghton, J., Ding, Y., Griggs, D., Noguer, M., van der Linden, P., Dai, X., Maskell, K., Johnson, C. (Eds.), 2001. Climate Change 2001: The Scientific Basis, Contribution of Working Group I to the Third Assessment Report of the Intergovernmental Panel on Climate Change. Cambridge University Press, Cambridge.

Hsü, K.J., McKenzie, J., 1985. A "Strangelove" ocean in the earliest Tertiary. In: Sundquist, E., Broecker, W. (Eds.), The Carbon Cycle and Atmospheric $\mathrm{CO}_{2}$ : Natural Variations Archean to Present, Geophysical Monograph, vol. 32. American Geophysical Union, Washington, DC, pp. 487-492.

Jessberger, E.K., Kissel, J., 1991. Chemical properties of cometary dust and a note on carbon isotopes. In: Newburn, R., Neugebauer, M., Rahe, J. (Eds.), Comets in the Post-Halley Era. Kluwer Academic Publishers, Amsterdam, pp. 1075-1092.

Jewitt, D., Matthews, H., Owen, T., Meier, R., 1997. Measurements of ${ }^{12} \mathrm{C} /{ }^{13} \mathrm{C},{ }^{14} \mathrm{~N} /{ }^{15} \mathrm{~N}$, and ${ }^{32} \mathrm{~S} /{ }^{34} \mathrm{~S}$ ratios in Comet Hale-Bopp $(\mathrm{C} /$ 1995 O1). Science 278, 90-93.

Kahn, A., Aubry, M.-P., 2004. Provincialism during the Paleocene/ Eocene thermal maximum: temporal constraint. Marine Micropaleontology 52, 117-131.

Kaiho, K., Nakamura, M., Cramer, B., Hussein, A., Lamolda, M., 2003. Extensive fires immediately preceded the extreme warming and benthic extinction event at the Paleocene/Eocene boundary. In: Lamolda, M.A. (Ed.), Bioevents: Their Stratigraphic Records, Patterns and Causes, Caravaca de la Cruz, June 3-8, 2003. Abstract Book, p. 114

Katz, M., Pak, D., Dickens, G., Miller, K., 1999. The source and fate of massive carbon input during the latest Paleocene thermal maximum. Science 286, 1531-1533.

Katz, M., Cramer, B., Mountain, G., Katz, S., Miller, K., 2001. Uncorking the bottle: What triggered the Paleocene-Eocene thermal maximum methane release? Paleoceanography 16 (6), $549-562$.

Katz, M., Katz, D., Wright, J., Miller, K., Pak, D., Shackleton, N., Thomas, E., 2003. Early Cenozoic benthic foraminiferal isotopes: species reliability and interspecies correction factors. Paleoceanography 18, 1024.

Kelly, D.C., 2002. Response of Antarctic (ODP Site 690) planktonic foraminifera to the Paleocene-Eocene thermal maximum: faunal evidence for ocean/climate change. Paleoceanography 17 (4), 1071.

Kelly, D.C., Bralower, T.J., Zachos, J.C., Premoli-Silva, I., Thomas, E., 1996. Rapid diversification of planktonic foraminifera in the tropical Pacific (ODP Site 865) during the late Paleocene thermal maximum. Geology 24, 423-426.

Kennett, J., Stott, L., 1990. Proteus and Proto-Oceanus: Ancestral Paleogene oceans as revealed from Antarctic stable isotopic results; ODP Leg 113. In: Barker, P., Kennett, J., et al., (Eds.), Proceedings of the Ocean Drilling Program, Scientific Results, vol. 113. Ocean Drilling Program, College Station, TX, pp. 865-880.

Kennett, J., Stott, L., 1991. Abrupt deep-sea warming, palaeoceanographic changes and benthic extinctions at the end of the Palaeocene. Nature 353, 225-229.

Kent, D., Cramer, B., Lanci, L., Wang, D., Wright, J., Van der Voo, R., 2003a. A case for a comet impact trigger for the Paleocene/ Eocene thermal maximum and carbon isotope excursion. Earth and Planetary Science Letters 211, 13-26.

Kent, D., Cramer, B., Lanci, L., Wang, D., Wright, J., Van der Voo, R., 2003b. Reply to a comment on "A case for a comet impact trigger for the Paleocene/Eocene thermal maximum and carbon isotope excursion" by G.R. Dickens and J.M. Francis. Earth and Planetary Science Letters 217, 201-205.

Knox, R., Aubry, M.-P., Berggren, W., Dupuis, C., Ouda, K., Magioncalda, R., Soliman, M., 2003. The Qreiya Section at Gebel Abu Had: Lithostratigraphy, clay mineralogy, geochemistry and biostratigraphy. Micropaleontology 49 (supplement no. 1), $93-104$.

Koch, P., Zachos, J., Gingerich, P., 1992. Correlation between isotope records in marine and continental carbon reservoirs near the Palaeocene/Eocene boundary. Nature $358,319-322$.

Koch, P., Zachos, J., Dettman, D., 1995. Stable isotope stratigraphy and paleoclimatology of the Paleogene Bighorn Basin (Wyoming USA). Palaeogeography, Palaeoclimatology, Palaeoecology $115,61-89$.

Koch, P., Clyde, W., Hepple, R., Fogel, M., Wing, S., Zachos, J., 2003. Carbon and oxygen isotope records from paleosols spanning the Paleocene-Eocene boundary, Bighorn Basin, Wyoming. In: Wing, S., Gingerich, P., Schmitz, B., Thomas, E. (Eds.), Causes and Consequences of Globally Warm Climates in the Early Paleogene, Special Paper, vol. 369. Geological Society of America, Boulder, CO, pp. 49-64.

Kurtz, A., Kump, L., Arthur, M., Zachos, J., Paytan, A., 2003. Early Cenozoic decoupling of the global carbon and sulfur cycles. Paleoceanography 18 (4), 1090.

Lanci, L., Kent, D., 2003. Introduction of thermal activation in forward modeling of hysteresis loops for single-domain magnetic particles and implications for the interpretation of the Day diagram. Journal of Geophysical Research 108 (B3), 2142.

Lanci, L., Kent, D., Miller, K., 2002. Detection of Late Cretaceous and Cenozoic sequence boundaries on the Atlantic coastal plain using core log integration of magnetic susceptibility and natural gamma ray measurements at Ancora, New Jersey. Journal of Geophysical Research 107 (B10), 2216.

Maas, M., Anthony, M., Gingerich, P., Gunnell, G., Krause, D., 1995. Mammalian generic diversity and turnover in the late Paleocene and early Eocene of the Bighorn and Crazy Mountain Basins, Wyoming and Montana (USA). Palaeogeography, Palaeoclimatology, Palaeoecology 115, 181-207.

Matsumoto, R., 1995. Causes of the $\delta^{13} \mathrm{C}$ anomalies of carbonates and a new paradigm "gas-hydrate hypothesis". Journal of the Geological Society of Japan 101, 902-924. 
Messenger, S., 2000. Identification of molecular-cloud material in interplanetary dust particles. Nature 404, 968-971.

Milkov, A., 2004. Global estimates of hydrate-bound gas in marine sediments: How much is really out there? Earth Science Reviews 66 (3-4), $183-197$.

Milkov, A., Sassen, R., 2003. Two-dimensional modeling of gas hydrate decomposition in the northwestern Gulf of Mexico: significance to global change assessment. Global and Planetary Change 36, 31-46.

Milkov, A., Claypool, G., Lee, Y.-J., Xu, W., Dickens, G., Borowski, W., 2003. In situ methane concentrations at Hydrate Ridge, offshore Oregon: new constraints on the global gas hydrate inventory from an active margin. Geology 31 (10), $833-836$.

Newell, A.J., Merrill, R.T., 2000. Size dependence of hysteresis properties of small pseudo-single-domain grains. Journal of Geophysical Research 105 (B8), 19393-19404.

Norris, R., Firth, J., 2002. Mass wasting of Atlantic continental margins following the Chicxulub impact event. In: Koeberl, C., MacLeod, K. (Eds.), Catastrophic Events and Mass Extinctions: Impacts and Beyond, Special Paper, vol. 356. Geological Society of America, Boulder, CO, pp. 79-95.

O'Keefe, J., Ahrens, T., 1989. Impact production of $\mathrm{CO}_{2}$ by the Cretaceous/Tertiary extinction bolide and the resultant heating of the Earth. Nature 338, 247-249.

Olsson, R., Miller, K., Browning, J., Wright, J., Cramer, B., 2002. Sequence stratigraphy and sea-level change across the Cretaceous-Tertiary boundary on the New Jersey passive margin. In: Koeberl, C., MacLeod, K. (Eds.), Catastrophic Events and Mass Extinctions: Impacts and Beyond, Special Paper, vol. 356. Geological Society of America, Boulder, CO, pp. 97-108.

Pak, D., Miller, K., 1992. Paleocene to Eocene benthic foraminiferal isotopes and assemblages: implications for deepwater circulation. Paleoceanography 7, 405-422.

Rehder, G., Brewer, P., Peltzer, E., Friederich, G., 2002. Enhanced lifetime of methane bubble streams within the deep ocean. Geophysical Research Letters 29 (15), 1731.

Royer, D., Berner, R., Beerling, D., 2001. Phanerozoic atmospheric $\mathrm{CO}_{2}$ change: evaluating geochemical and paleobiological approaches. Earth-Science Reviews 54, 349-392.

Schmitz, B., Asaro, F., Molina, E., Monechi, S., von Salis, K., Speijer, R., 1997. High-resolution iridium, $\delta^{13} \mathrm{C}, \delta^{18} \mathrm{O}$, foraminifera and nannofossil profiles across the latest Paleocene benthic extinction event at Zumaya, Spain. Palaeogeography, Palaeoclimatology, Palaeoecology 133, 49-68.

Schmitz, B., Peucker-Ehrenbrink, B., Heilmann-Clausen, C., Åberg, G., Asaro, F., Leef, C.-T., 2004. Basaltic explosive volcanism, but no comet impact, at the Paleocene-Eocene boundary: high-resolution chemical and isotopic records from Egypt, Spain and Denmark. Earth and Planetary Science Letters $225(1-2), 1-17$.

Shackleton, N., 1986. Paleogene stable isotope events. Palaeogeography, Palaeoclimatology, Palaeoecology 57, 91-102.

Shackleton, N., Kennett, J., 1975. Paleotemperature history of the Cenozoic and the initiation of Antarctic glaciation: Oxygen and carbon isotope analyses in DSDP Sites 277, 279, and 281. In: Kennett, J., Houtz, R., et al., (Eds.), Initial Reports of the Deep
Sea Drilling Project, vol. 29. U.S. Government Printing Office, Washington, pp. 743-755.

Siegenthaler, U., Sarmiento, J., 1993. Atmospheric carbon dioxide and the ocean. Nature $365,119-125$.

Speijer, R., Morsi, A.-M., 2002. Ostracode turnover and sea-level changes associated with the Paleocene-Eocene thermal maximum. Geology 30, 23-26.

Steineck, P., Thomas, E., 1996. The latest Paleocene crisis in the deep sea: Ostracode succession at Maud Rise, Southern Ocean. Geology 24, 583-586.

Steurbaut, E., Magioncalda, R., Dupuis, C., Van Simaeys, S., Roche, E., Roche, M., 2003. Palynology, paleoenvironments, and organic carbon isotope evolution in lagoonal PaleoceneEocene boundary sections in North Belgium. In: Wing, S., Gingerich, P., Schmitz, B., Thomas, E. (Eds.), Causes and Consequences of Globally Warm Climates in the Early Paleogene, Special Paper, vol. 369. Geological Society of America, Boulder, CO, pp. 291-317.

Stoll, H., Bains, S., 2003. Coccolith $\mathrm{Sr} / \mathrm{Ca}$ records of productivity during the Paleocene-Eocene thermal maximum from the Weddell Sea. Paleoceanography 18 (2), 1049.

Stott, L., 1992. Higher temperatures and lower oceanic $p \mathrm{CO}_{2}$ : A climate enigma at the end of the Paleocene Epoch. Paleoceanography 7, 395-404.

Stott, L., Kennett, J., Shackleton, N., Corfield, R., 1990. The evolution of Antarctic surface waters during the Paleogene: Inferences from the stable isotopic composition of planktonic foraminifers. In: Barker, P., Kennett, J., et al., (Eds.), Proceedings of the Ocean Drilling Program, Scientific Results, vol. 113. Ocean Drilling Program, College Station, TX, pp. 849-864.

Stott, L., Sinha, A., Thiry, M., Aubry, M.-P., Berggren, W., 1996. Global $\delta^{13} \mathrm{C}$ changes across the Paleocene-Eocene boundary: criteria for terrestrial-marine correlations. In: Knox, R., Corfield, R., Dunay, R. (Eds.), Correlation of the Early Paleogene in Northwest Europe, Special Publication, vol. 101. Geological Society, London, pp. 381-399.

Svensen, H., Planke, S., Malthe-Sørenssen, A., Jamtveit, B., Myklebust, R., Eidem, T., Rey, S., 2004. Release of methane from a volcanic basin as a mechanism for initial Eocene global warming. Nature 429, 542-545.

Thomas, E., 1998. Biogeography of the late Paleocene benthic foraminiferal extinction. In: Aubry, M.-P., Lucas, S., Berggren, W. (Eds.), Late Paleocene-Early Eocene Climatic and Biotic Events in the Marine and Terrestrial Records. Columbia University Press, New York, pp. 214-243.

Thomas, E., 2003. Extinction and food at the seafloor: a highresolution benthic foraminiferal record across the Initial Eocene Thermal Maximum, Southern Ocean Site 690. In: Wing, S., Gingerich, P., Schmitz, B., Thomas, E. (Eds.), Causes and Consequences of Globally Warm Climates in the Early Paleogene, Special Paper, vol. 369. Geological Society of America, Boulder, CO, pp. 319-332.

Thomas, E., Shackleton, N., 1996. The Paleocene-Eocene benthic foraminiferal extinction and stable isotope anomalies. In: Knox, R., Corfield, R., Dunay, R. (Eds.), Correlation of the Early Paleogene in Northwest Europe, Special Publication, vol. 101. Geological Society, London, pp. 401-441. 
Thomas, D., Bralower, T., Zachos, J., 1999. New evidence for subtropical warming during the late Paleocene thermal maximum: stable isotopes from Deep Sea Drilling Project Site 527, Walvis Ridge. Paleoceanography 14, 561-570.

Thomas, E., Zachos, J., Bralower, T., 2000. Deep-sea environments on a warm earth: latest Paleocene-early Eocene. In: Huber, B., MacLeod, K., Wing, S. (Eds.), Warm Climates in Earth History. Cambridge University Press, Cambridge, UK, pp. 132-160.

Thomas, D., Zachos, J., Bralower, T., Thomas, E., Bohaty, S., 2002. Warming the fuel for the fire: evidence for the thermal dissociation of methane hydrate during the Paleocene-Eocene thermal maximum. Geology 30, 1067-1070.

Thomas, D., Bralower, T., Jones, C., 2003. Neodymium isotopic reconstruction of late Paleocene-early Eocene thermohaline circulation. Earth and Planetary Science Letters 209, 309-322.

Toggweiler, J., 1999. Variation of atmospheric $\mathrm{CO}_{2}$ by ventilation of the ocean's deepest water. Paleoceanography 14, 571-588.

Tripati, A., Elderfield, H., 2004. Abrupt hydrographic changes in the equatorial Pacific and subtropical Atlantic from foraminiferal $\mathrm{Mg} / \mathrm{Ca}$ indicate greenhouse origin for the thermal maximum at the Paleocene-Eocene Boundary. Geochemistry, Geophysics, Geosystems 5 (2), Q02006.

Verma, H., Upadhyay, C., Tripathi, R., Tripathi, A., Shukla, A., Bhandari, N., 2001. Nano-sized iron phases at the K/T and P/T boundaries revealed by Mössbauer spectroscopy. In: Preliminary Program, 32nd Lunar and Planetary Science Conference, March 12-16, 2001, Houston, TX. p. 1270.
Wdowiak, T., Armendarez, L., Agresti, D., Wade, M., Wdowiak, S., Claeys, P., Izett, G., 2001. Presence of an iron-rich nanophase material in the upper layer of the Cretaceous-Tertiary boundary clay. Meteoritics and Planetary Science 36, 123-133.

Wilde, P., Quinby-Hunt, M., 1997. Collisions with ice/volatile objects: geological implications - a qualitative treatment. Palaeogeography, Palaeoclimatology, Palaeoecology 132, 47-63.

Wyckoff, S., Kleine, M., Peterson, B., Wehinger, P., Ziurys, L., 2000. Carbon isotope abundances in comets. The Astrophysical Journal 535, 991-999.

Xu, W., Ruppel, C., 1999. Predicting the occurrence, distribution, and evolution of methane gas hydrate in porous marine sediments. Journal of Geophysical Research 104, 5081-5096.

Zachos, J., Arthur, M., Dean, W., 1989. Geochemical evidence for suppression of pelagic marine productivity at the Cretaceous/ Tertiary boundary. Nature 337, 61-64.

Zachos, J., Lohmann, K., Walker, J., Wise, S., 1993. Abrupt climate change and transient climates during the Paleogene: a marine perspective. Journal of Geology 101, 191-213.

Zachos, J., Pagani, M., Sloan, L., Thomas, E., Billups, K., 2001. Trends, rhythms, and aberrations in global climate $65 \mathrm{Ma}$ to present. Science 292, 686-693.

Zachos, J., Wara, M., Bohaty, S., Delaney, M., Petrizzo, M., Brill, A., Bralower, T., Premoli-Silva, I., 2003. A transient rise in tropical sea surface temperature during the Paleocene-Eocene thermal maximum. Science 302, 1551-1554. 